\title{
Flows, system boundaries and the politics of urban metabolism: waste management in Mexico City and Santiago de Chile
}

\begin{abstract}
:
In this paper we examine two central concepts of urban metabolism ('system boundaries' and 'flows'), and explore how to approach them as a means to politicise urban metabolism research. We present empirical findings from two case studies of waste management, in Mexico City and Santiago de Chile, looking at: the materiality of waste flows, the actors involved in them, and how waste flows relate to issues of environmental justice. We argue that urban metabolism, as a methodology to understand urban sustainability, has the potential to produce knowledge to trigger urban transformations, and to analyse the social, political and environmental aspects of waste management in urban areas.
\end{abstract}

Keywords: political-industrial ecology, urban metabolism, waste management, Mexico City, Santiago de Chile

\section{Introduction}

Urban metabolism is a framework that takes material flows as the unit of analysis to describe patterns of natural resources transformation in cities. Urban metabolism analyses have been used in the field of Industrial Ecology to identify pathways to improve the sustainability of these flows. Yet, because of its emphasis on the environmental efficiency of the urban system as a whole, urban metabolism has not effectively engaged with the institutional and political contexts which shape and are influenced by urban material flows. Calls for a 'politicisation' of urban metabolism have ensued (Newell \& Cousins, 2014; Delgado Ramos, 2014), building on a rich debate about the politics of urban metabolism (Heynen, Kaika, \& Swyngedouw, 2006; Heynen, 2013; Keil, 2005).

Beyond its instrumental use in eco-efficiency studies, urban metabolism enables deep analyses of the politics of urban ecologies (Castán Broto, Allen, \& Rapoport, 2012). Particularly, political geographers have shown that urban metabolism ideas make explicit how politics are embedded in specific forms of material circulation in capitalist economies and the production of new types of urban inequality (Swyngedouw, 2006, Keil, 2005). There is thus a growing interest in the potential of urban metabolism methods of urban analysis to facilitate just transitions to urban sustainability (Swilling \& Annecke, 2012). However, engaging with these questions requires a refinement of urban metabolism's approaches. Analysing the principles and assumptions of knowledge production (their doxa) is a means to critically expose the political work of knowledge legitimisation and its governance consequences (Castán Broto, 2013). We suggest that can be done by revisiting two of its central analytical concepts: system 
boundaries and flows. While system boundaries relate to the delimitation of the problem of study in Industrial Ecology, the concept of flow relates to the ontological assumptions that underpin the conceptions of the city that are mobilised in urban metabolism analyses.

This is evident in the management of urban waste flows. Waste is an object which is conceptualized either as disposable or reusable, through the assignation of meaning as part of its active integration in society (Moore, 2012). From the health impacts of waste management, to the way it supports the interests of diverse actors from waste pickers to global businesses, urban waste flows are embedded in multi-layered systems of governance (Hoornweg \& BhadaTata, 2012). The political dimensions of resource flows become explicit in specific contexts: we focus on the cases of Mexico City and Santiago de Chile, to develop a comparative analysis of the influence of urbanisation patterns and local politics on the configuration of waste flows. Urban metabolism serves here as a framework to relate material circulation to the role of different actors in waste collection, revealing context-specific patterns of injustice. The comparative analysis suggests that urban metabolism can be appropriated as a method for progressive analyses of environmental injustices as long as its fundamental assumptions are put under critical scrutiny.

\section{Understanding the city of resource flows}

Urban metabolism is an analytical framework that studies urban material flows; that is, the processes of consumption and transformation of materials in the urban system. An Industrial Ecology approach to urban metabolism follows a functionalist perspective to quantify environmental flows through the urban system in order to manage the city's overall consumption and waste (see for instance: Barles, 2009; Kennedy, Cuddihy \& Engel-Yan, 2007; Wolman, 1965). Material Flow Analysis (MFA) measures the input and output of materials being consumed and disposed by an administrative region (Brunner \& Rechberger, 2004) and Life Cycle Assessment (LCA) tracks materials through their industrial lifecycle (Goldstein, Birkved, Quitzau, \& Hauschild, 2013). These methods have been used to produce strong accounts of urban material flows (Alfonso Piña \& Pardo Martínez, 2013; Kennedy, Pincetl \& Bunje, 2011; Rosado, Niza \& Ferrao, 2014), their climate impacts (Delgado Ramos, Campos Chávez \& Rentería Juárez, 2012), the resource cycle (Forkes, 2007; Villarroel Walker \& Beck, 2012), and the relationship between a city and its hinterland (Barles, 2009). Urban metabolism has been used to study waste flows in both Mexico City (Delgado Ramos, 2012) and Santiago de Chile (Wackernagel, 1998), using city-wide data and per capita averages. These studies consider solid waste as a significant flow linked to unsustainable patterns of land use, energy 
consumption and land/air/water pollution; however, the methods used to produce these quantitative accounts are based on specific assumptions about the urban system, the material flows, and how these can be represented. We argue here that questioning these assumptions is a way to politicize the urban metabolism framework. To do so, we build on a body of literature, often grouped under the umbrella term 'Urban Political Ecology' (UPE), which relates urban metabolism to the production of environmental injustices in the city, as resource flows are embedded in processes of material accumulation (Cook \& Swyngedouw, 2012; Heynen, Kaika, $\&$ Swyngedouw, 2006). Methodologies like Material Flows Analysis have the potential to reveal material politics as they unfold in urban areas, but only if its fundamental assumptions are put under scrutiny.

The first assumption is one of system boundaries: within Industrial Ecology, urban metabolism research focuses on the city as the object of study and frames it as a homogenous, static entity. Once the system boundaries are set around the city, it becomes impossible to look at what happens within, outside or beyond the urban system: material flows become an indistinct "black matter" that veils the specific modes in which the flows circulate and inequalities are embedded in these flows. However, material flows cannot always be studied by looking at the city scale alone: looking at the case of water flows in Mumbai, McFarlane (2013, p.499) argues that "addressing [...] metabolic inequalities requires more than addressing water alone": this means looking at processes that affect water use, such as housing, water saving practices or agricultural policy. Likewise, it is necessary to look beyond the city scale, within homes, municipal offices, corporate practices, or irrigation pipes (McFarlane, 2013, pp.498-499). Recognising that natural resources flows are not just material, but are entangled with spatial, social and political practices, which are embedded in a particular place, is a first step towards politicizing urban metabolism research. In order to do so, it is necessary to challenge the conceptualisation of the city as a "black-box", looking instead at processes of urbanisation in the flows are produced and circulated, regardless of their scale.

The second assumption relates to how flows are conceptualised. In an Industrial Ecology framework, flows are conceptualised as items that can be isolated in space and time, in order to be quantified. However, framing flows in this way de facto restrains which flows can be included in the research: some flows cannot be quantified (for instance, because there is no data readily available about them, or because they evolve very rapidly and thus cannot be estimated for a specific point in time), and thus tend to not be included in Industrial Ecology research. On the other hand, not all the interesting data about material flows is of a quantitative nature. Flows also matter because of the people who interact with the material, which practices 
these flows enable, and how they distribute power in a context of capitalist globalisation. As such, waste workers, their daily lives, values, and working conditions should be an essential aspect of a waste metabolism analysis. Thus, we propose a conceptualisation of waste flows as dynamic, not always -or not fully- quantifiable, and as related to other components of the urban system, such as society, workers, productive activities, and governance.

Material Flow Analysis is approached not as a rigid framework but rather as a datagathering tool through which different actors can be engaged in producing narratives about resources flows in their city; the overall objective being to build a political analysis of material flows that is pluralistic and addresses issues of environmental justice (see Guibrunet \& Castán Broto (2016) for theoretical background, and Demaria \& Schindler (2015) for an empirical example).

\section{$\underline{\text { 3. Debates around urban waste management in the Latin American context }}$}

The management of domestic solid waste has implications for all aspects of urban sustainability (UN-Habitat, 2010). In cities where waste collection rates are low, improving the waste management system is first and foremost a public health imperative. Additionally, waste that is not processed properly has negative environmental impacts (such as greenhouse gas emissions or production of toxic by-products). Waste management poses, on the one hand, an economic challenge for local authorities (being one of the highest expenditures of municipalities in low-income countries) and on the other hand, provides livelihoods for the urban poor (up to five percent of urban dwellers in low-income countries). This has both positive economic and social impacts: socially, it provides a livelihood to marginalised urban dwellers (who have no other access to work, because of low education levels, drug addiction, age...). Economically, it provides the basis for a thriving local economy (Ezrah, Fazakerley \& Roberts, 2013; Hoornweg \& Bhada-Tata, 2012, Le Courtois, 2012).

The local governance system (political, legal and administrative frameworks) shapes how waste management services are run (UN-Habitat, 2010). For example, waste management systems are shaped by social and institutional relations including: political interests and clientelism, public administration changes and their timeframes, financial pressures and funding sources, public opinion, relationship between stakeholders (such as existing collaboration, or ongoing conflicts), and the governance capacity of local authorities (Ali, Olley, \& Cotton, 1999; Bhuiyan, 2010; Castillo Berthier, 2003; Ezeah, Fazakerley, \& Roberts, 2013; Schindler \& Kishore, 2015; Sembiring \& Nitivattananon, 2010). Looking at the case of 
Mexico, Castillo Berthier (2003) highlights how relations of patronage ('clientelism') and the rule of local leaders or 'caciques' play a defining role in waste management services. Caciquism is a way of making informal politics where an autocratic leader mediates negotiations between civil servants and informal groups. For example, informal waste handlers' right to work in certain areas of the city (for instance, to pick waste on a landfill) and their working conditions are determined on a case by case basis, through informal negotiations between street leaders and local authorities, often in exchange for political favours (for instance, voting for a specific party, or creating a cheering crowd at political rallies) (Castillo Berthier, 2003).

In Latin America, regular services of waste collection are common in most cities, but too often they are unequal, unaccountable and unreliable (Hardoy, Mitlin, \& Satterthwaite, 2013; Acurio et al., 1997). Facing severe technical and economic limitations, numerous local authorities have privatised waste management services, whether through contracting models or through public-private partnerships (Terraza, 2009; Costa Leite, 1997). This has led to an increasing number of actors playing a role in urban waste management; and particularly a series of intermediaries, operating in the blurry spaces between the service provider, regulator and user (Guy, Marvin, Medd, \& Moss, 2011; Moss, Medd, Guy, \& Marvin, 2009).

Intermediaries are involved in a heterogeneous array of waste management activities which can be characterised alongside a continuous spectrum of formal and informal practices. The informal sector, integrated by a myriad of independent workers and family businesses who engage in waste management as a subsistence activity, is most often understood at lying "out of state control" (Ezeah et al., 2013, p.2510). Informal street sweepers, household wastecollectors, helpers to the municipal collection crew, and waste-pickers in the streets and on the landfills, collect, process, transport and trade waste alongside workers from the public and private sector (Medina, 2000, 2005; van Beukering, 1994; Wilson, Rodic, Scheinberg, Velis, \& Alabaster, 2012). Research on these activities has documented the working conditions and livelihoods of informal waste-pickers, often characterised by exploitation, poverty and risks to workers' health (see for instance: Beall, 1997; Castillo Berthier, 1984; Hunt, 1996; Huysman, 1994; Moreno-Sanchez \& Higinio Maldonado, 2006).

Recent assessments have also examined the contribution of informal workers to urban waste management systems, and the associated sustainability impacts (Benson, 2014; Ezeah et al., 2013; Vergara, Damgaard, \& Gomez, 2015; Wilson, Araba, Chinwah, \& Cheeseman, 2009). One of the main findings of this literature, consistent throughout the Global South, is the dependence of the formal urban waste management systems on a variety of informal 
components. Firstly, there is evidence of informal recyclers providing essential inputs (in the shape of raw material) to formal industries (Chi, Streicher-Porte, Wang, \& Reuter, 2011; Streicher-Porte et al., 2005; Wilson et al., 2009). For instance, in their analysis of an e-waste recycling hub in Accra, Ghana, Grant \& Oteng-Ababio (2012) explain that governmentrecognised businesses depend on informal workers through outsourcing and sub-contracting. They also receive their main input, selected e-waste, from informal workers. The wide diversity of informal waste work (buying, selecting, gathering, processing, disassembling e-waste) is thus central to this urban e-waste economy in a process that the authors refer to as "normalisation of informality" (Grant \& Oteng-Ababio, 2012, p.18). Similar observations about the close interactions between the putatively separated formal and informal waste management sectors have been made in other contexts, such as China (Chi et al., 2011), Vietnam (Kawai, Osako, Matsui, \& Dong, 2012), and Mexico (Frykman, 2006; Hilburn, 2015).

In Latin America, the informal sector also plays a key role in improving and extending the coverage of waste collection services. In the case of urban Mexico, cartoneros collect domestic refuse where municipal collection is lacking (Medina, 2005). This is particularly common in informal settlements where households do not pay local taxes, or in municipalities with low financial capacities. Independent workers, using pushcarts or trolleys, collect domestic waste from households for a small fee. They then dispose of it in sanitary landfills or local municipal transfer stations. Medina suggests that, in this way, informal workers complement the work of municipal collection crews, particularly in those neighbourhoods where the municipal service cannot be provided. ${ }^{1}$

Scheinberg et al (2011) characterise waste management services as an arrangement of "modernised mixtures" of high-tech and centralised models on infrastructure management coexisting along small-scale, decentralised ones (based on work by Guy, Marvin and Moss, 2001). Private and informal actors are a force to be reckoned with in waste management systems in Latin American cities, although the size and manner of their contribution will depend on the context in which they operate. Most authors establish a link between the wellbeing of informal workers and the role that they play in facilitating the recycling and reuse of waste, hence improving the environmental health of the whole city (Ahmed \& Ali, 2004; Ali, 2004; Chi et al., 2011; Ezeah et al., 2013; Medina, 2000; Rouse, 2006; WIEGO, n.d.; Wilson et al., 2009). Yet, despite the evidence, policy makers tend to perceive informal workers

\footnotetext{
${ }^{1}$ In parallel, high-income households and big commercial waste producers (such as malls of offices) may also choose to pay for private waste collection services, in addition to paying their local taxes.
} 
as a negative influence in the waste management system (see Medina, 2000; Sembiring \& Nitivattananon, 2010; Nzeadibe, 2009). Successfully integrating informal workers in waste management policies remains a challenge (for positive examples, see: Wilson et al., 2012), and more research is needed to better understand the role of informal waste workers in diverse contexts.

An urban metabolic analysis of waste flows helps understand the role played by informal workers in a given city, and hence, may constitute a tool to empower those who not only play a crucial role in the overall system, but also may bear the greatest burden. Reflecting critically on the methodological possibilities of urban metabolism may help exposing the materiality of waste flows, the role of key actors in these flows, and how their operation is shaped by specific patterns of local politics.

\section{Methodology}

\subsection{Selection of the two case studies}

Taking into account the debates on critical and innovative approaches to urban studies amidst the increasing complexity of globalisation, particularly those proposals for a comparative urbanism (such as Dear 2005 or Nijman, 2007), we choose to build an analysis based on empirical research in two Latin-American case studies, Mexico City and Santiago de Chile. Following the attempts to develop an 'experimental' comparative urbanism (McFarlane \& Robinson, 2012) and the challenges it poses to theorisation of wider scales (Robinson, 2015) this article is grounded in a combination of research methods that confronts data from two very different districts in cities subjected to recognisable -similar and different- processes.

Mexico City and Santiago de Chile are increasingly globalised, complex and spatially growing metropolis in which waste management is a critical issue in terms of urban and environmental governance (Centro Mario Molina, 2014; CONAMA 2010; Sabatini and Wormald, 2004). These cities have different socio-economic dynamics: metropolitan Santiago barely reaches seven million inhabitants whilst metropolitan Mexico City exceeds twenty million inhabitants; absolute poverty and lack of sanitation infrastructure is more striking in Mexico City, although Santiago's rate of income inequality (by Gini coefficient) is higher (Major et al. 2011; MIDEPLAN 2015; UN-Habitat, 2010).

Both these cities are to some extent characterised by ongoing processes of neoliberalism which shape urban development (see Kaminer et al., 2011). Although there is evidence that neoliberal policies have been contested and reformed worldwide, critical scholars have also stressed the continuity of variegated forms of urban neoliberalisation (Brenner, Peck \& 
Theodore, 2010). Conscious of these processes, we choose neighbourhoods that represent two extremes in a similar process of splintered urban growth (following Graham and Marvin, 2001).

Tepito is a mixed-use urban neighbourhood of $1 \mathrm{~km}^{2}$ and 36,000 inhabitants only a few streets away from the historic city centre of Mexico City (see Figure 1).

Figure 1: Map of Mexico City's Metropolitan Area, and the neighbourhood of Tepito.

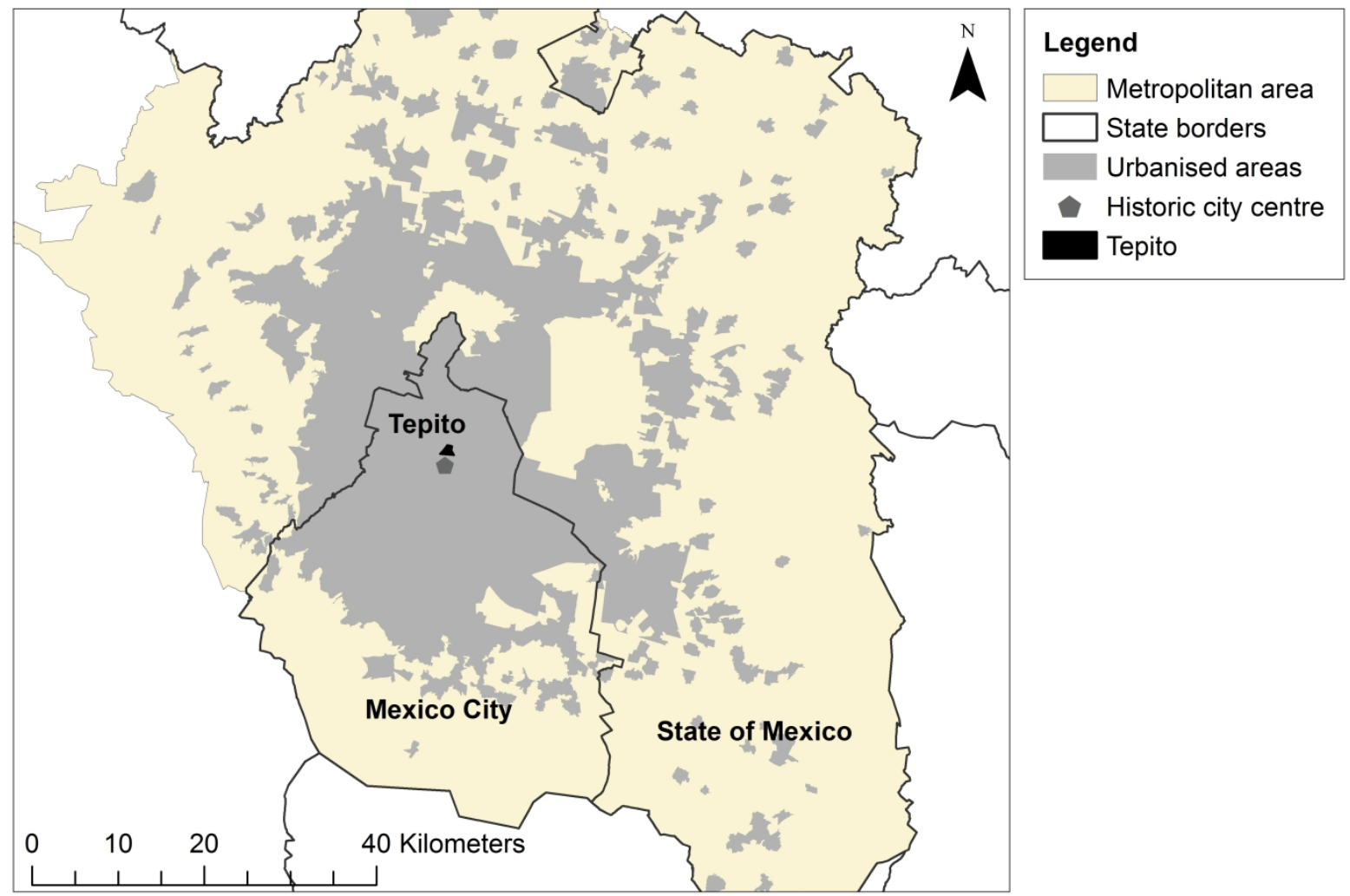

Its streets are occupied by an estimated 10,000 stalls with semi-permanent structures, making Tepito one of the most important informal markets in the city. Because of the informality of its labour market and retail activity -of both legal and pirated merchandise- this neighbourhood appears as a territory that develops its own mode of neoliberalisation. Simultaneously, Tepito represents in popular culture the capacity of people to fare on their own, without help from the government. Due to the prevalence of informal activities and the resistance to government institutions, a parallel political structure has developed where taxes are paid to caciques (rather than the municipality) who provide urban services, such as authorisations and licenses to sell in the street, legal support or waste collection services. Thus, in the main commercial streets of the neighbourhood, privately-hired street sweepers evacuate domestic waste towards the outskirts of the neighbourhood, where the municipality takes over. This relative independence from the municipality in terms of service provision (particularly 
waste management), as well as the density of residential and commercial activities in Tepito responsible for high levels of waste generation- make this neighbourhood a central case study to characterise the politics of waste flows in Mexico City.

Chicureo, with a typology of suburban neighbourhoods, country clubs and rural allotments condominiums, is one of the new and exclusive segregated residential districts that have developed since the 2000s in Colina, a peri-urban municipality North of Santiago de Chile (see Figure 2).

Figure 2: Map of Santiago de Chile's Metropolitan Area, and the neighbourhood of Chicureo.

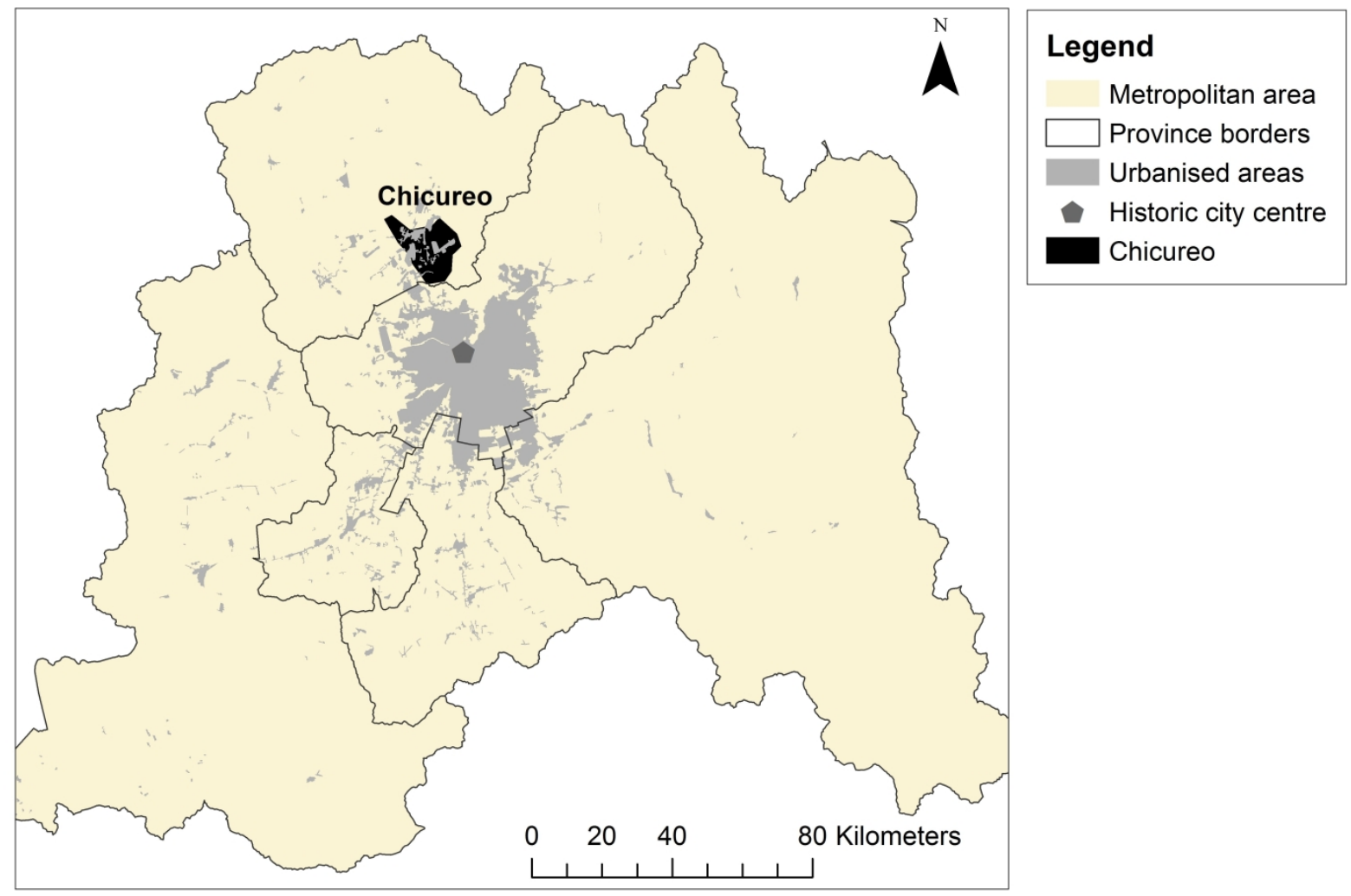

With an estimated population of over 30,000 inhabitants, Chicureo lies in a valley detached from Santiago by a range of Andean foothills, nearly $35 \mathrm{~km}$ from the city business and wealthy residential districts, to which it is connected by high-standard private motorways. Created as an experiment of fully privately-developed district, Chicureo has grown as a cluster of very large scale urban enclaves whose governance primarily depends on the initiative of property developers, water and sanitation utilities and large retail suppliers (Sanzana Calvet \& Castán Broto, 2016). Like Tepito, Chicureo is characterised by high levels of independence from central government and the circulation of large amounts of waste within a limited area. 
The waste metabolisms of Tepito and Chicureo are revealing insofar as their exploration challenges dominant discourses on waste at the city level: both cases represent invisible stories, overlooked by academics and ignored by city managers. We believe that by studying these politically-charged cases we can reveal insights about the material politics of the overall city. Additionally, the comparison of two contrasting cases (in terms of size, structure of the local economy, and social relations) allows us to examine how an urban metabolic analysis exposes the configuration waste flows - and their outcomes - in different contexts.

\subsection{Data collection}

In the case of Mexico City, the research was carried out over two stages of fieldwork, both taking place in 2015. As a first step, fifteen semi-structured interviews were conducted with academics, civil servants and international institutions representatives - all waste management or urban development experts. These interviews were used to compile the institutional knowledge on the role of different actors in the city's waste management. Then, exploratory field research was undertaken in Tepito: thirty unstructured interviews were conducted with waste workers (private and public-sector street sweepers, informal waste-pickers, owners and workers of recycling centres, municipality employees, particularly garbage collection truck drivers and voluntary helpers). Besides, a month-long observation was carried out in a small recycling centre, which helped both frame and analyse the aforementioned interviews.

The case of Santiago de Chile combines data from fieldwork and the revision of secondary sources. The fieldwork developed in two parts, both in 2013. It consisted of semi-structured interviews with sixty-one actors (including developers; civil servants at the local, regional and national level of government; scholars; residents in Chicureo; as well as activists and members of social organisations in the municipality of Colina). In these interviews, waste management and recycling was one among many subjects referring to urban metabolism and sustainability discourses. An online survey ${ }^{2}$ to enclaves' residents was developed as a strategy to gain information about their perception of everyday life. In addition, photos and ethnographic notes on Chicureo's everyday life were gathered through walking transects in four large enclaves, which included observation of the recycling facilities, domestic waste disposal and municipal waste collection. These primary sources were combined with an analysis of documents,

\footnotetext{
${ }^{2}$ Carried out through a commercial survey provider. Open to responses during 30 days with diffusion per email based on non-probability snowball sampling (see Sue and Ritter, 2012): achieved 57 respondents.
} 
including the national and local press, profiles of the enclave projects, reports from private utility companies, and official statements from authorities and regulators.

\subsection{Data analysis}

Our analysis follows three steps: first, we map waste flows through the industrial cycle. To do so, we 'follow the flows', that is, we systematically track waste flows from their origin (the moment they are labelled 'waste') to their end (the disposal site), analysing their impacts along the way. Results are compiled in a waste flows diagram, which shows how and where the waste is generated, collected, transported, processed, and how it is disposed of. Secondly, we identify the individuals or groups that produce, use, transport and transform waste. Data from interviews and observation enables linking material flows with the livelihoods and practices of accumulation that they enable; examining how they carry economic value and convey political power through the chain of actors. As a third step, we evaluate the impacts of material flows through interpretative analysis. The social, environmental and political impacts of material flows are identified with reference to actors' own narratives in unstructured interviews, and through ethnographical observations.

\section{Results: a comparative study of waste management in two cities}

\subsection{Waste management in Mexico City}

Every day, Mexico City's households and businesses produce 12,893 tons of solid waste (SEDEMA, 2015). This represents around $1.5 \mathrm{~kg}$ per inhabitant daily, ${ }^{3}$ above the world average of 1.2 (Hoornweg \& Bhada-Tata, 2012). While Mexican federal institutions produce laws and regulations for waste management, ${ }^{4}$ Mexico City's government is in charge of the waste management infrastructure, and in particular the disposal sites -such as landfills, recycling centres and composting stations. Within Mexico City, municipalities are legally responsible for waste collection and transport to the disposal sites. They are also in charge of the cleanliness of the streets and the smooth operation of the service provided to citizens.

Waste is a sector over which the government has relatively little control. The governmentorganised system of waste management (made up of the municipal street sweepers and

\footnotetext{
3 This figure is calculated with waste generation data $(12,893$ tons/day) and population data $(8,851,080)$ for Mexico City only, rather than the Metropolitan Area (see SEDEMA, 2015).

${ }^{4}$ The main document is the General Law for Prevention of Waste and Integral Waste Management first implemented in 2003 (Cámara de Diputados del Congreso de la Union, 2015). This document sets general guidelines for sound waste management, but leaves freedom to each state to design their own strategies as to waste prevention and management.
} 
collection trucks, as well as the city's waste treatment plants and landfills) is complemented by two alternative systems (See Figure 3 and 4). First, waste collection, transport and management can be privately organised (for instance, privately hired street sweepers at the neighbourhood scale). Second, informal workers (waste-pickers, voluntary helpers and recycling traders) pick out recyclables, process them and sell them (through a chain of intermediaries) to the recycling industry. The 'pepena' (for the indigenous Nahuatl language "to pick up") is the action of going through waste to pick out the recyclables or recoverable materials. This takes place at all stages of the waste management process: within residential and commercial buildings, in the collection truck (where "voluntary helpers" to the municipal team operate), in the street, and even in government recycling facilities and in landfills. In certain neighbourhoods, informal waste handlers outweigh municipal employees.

Figure 3. Informal waste-picker (first from the left), voluntary helpers (second and fourth from the left) and municipal collection crew (in orange uniforms) working alongside on the daily collection route, Tepito.

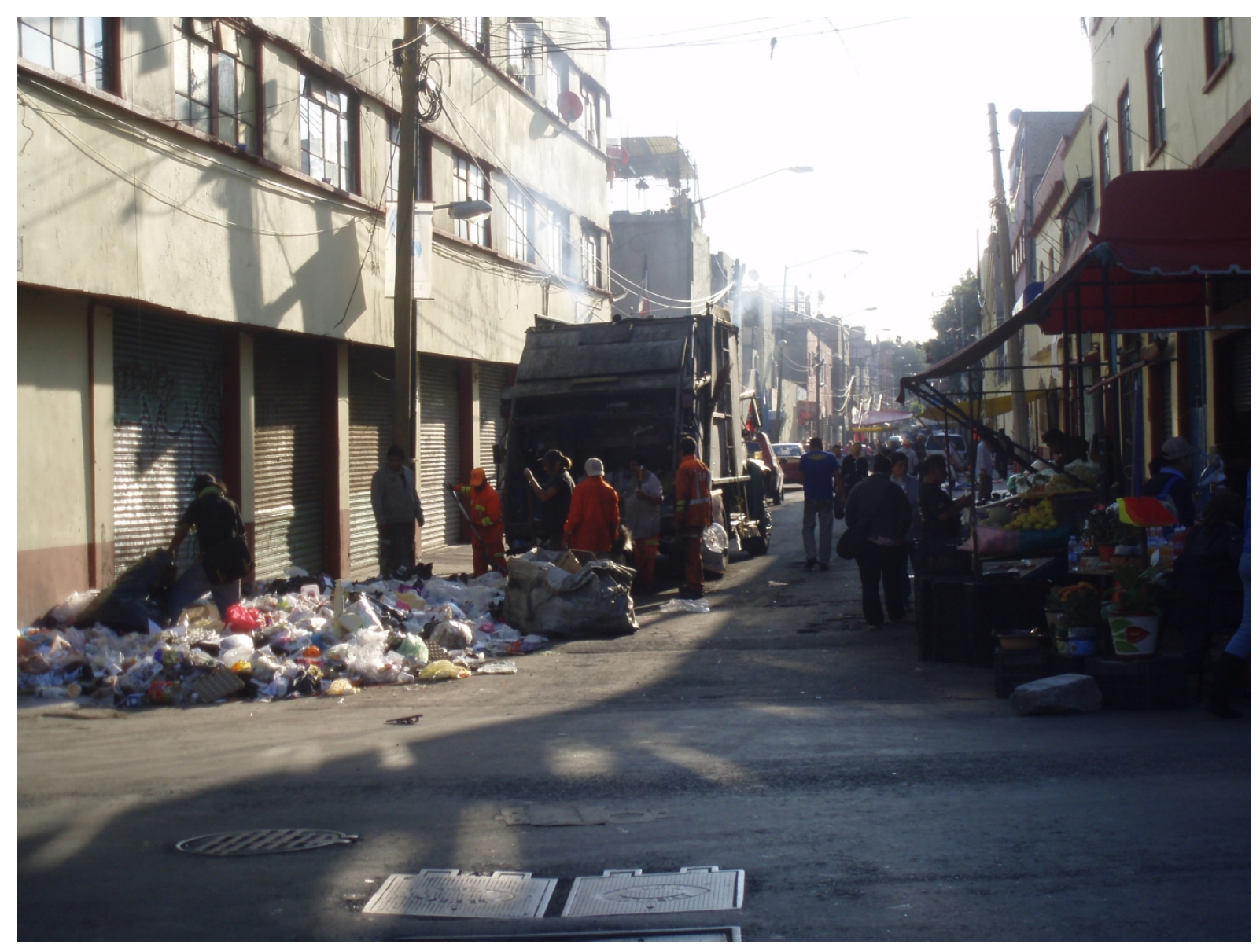

Credits: Louise Guibrunet, March 2016. 
Public, private and informal waste management are interdependent and intertwined: for instance, informal waste-pickers are allowed to work in government collection trucks, separation plants and landfills (Figure 3). Privately hired street sweepers and municipal employees also negotiate and coordinate their action so that their work does not overlap, and rather complements each other. Yet, this de facto collaboration is not recognised institutionally: official reports and urban waste strategies only address the public provision of waste collection and management services ${ }^{5}$; which means that there is no official record of informal workers' contribution to urban waste management.

\subsection{Tracking waste flows in the neighbourhood of Tepito}

Figure 4 shows the interaction of formal, informal and private waste flows in Tepito. In Tepito alone, informal waste handlers include dozens of street sweepers, hundreds of wastepickers and twelve recycling businesses who pick up, clean, process, transport and sell recoverable waste to the recycling industry. These actors live off what they pick out and trade. Waste that cannot be sold on the market (non-recyclables and organic waste) is left for the municipality to handle.

Figure 4: Diagram of waste flows in Tepito.

\footnotetext{
${ }^{5}$ See for instance the government's Solid Waste inventory (SEDEMA, 2015) or the Programme for the Integral Management of Solid Waste, Mexico City (Gobierno del Distrito Federal, 2010).
} 

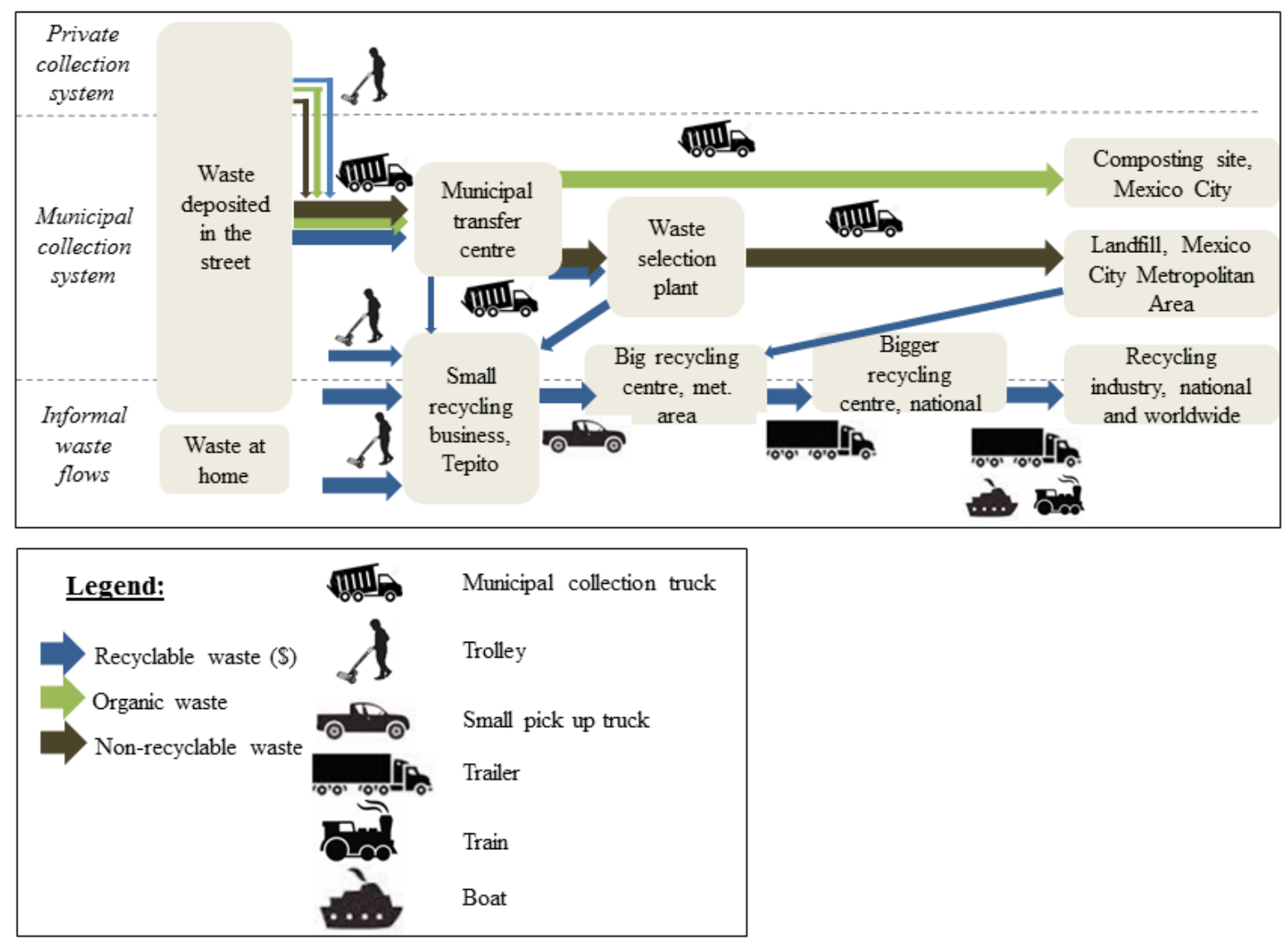

Interviews reveal that recyclable waste is primordially seen by waste handlers as a flexible means to earn a living which they could not earn in formal employment (for instance, because of a handicap, drug addiction or a police record). However, they also identify numerous health risks such as cutting oneself with syringes or glass, or being bitten by insects and rats. One interviewee, recalling his first days as a waste-picker (at seventy-five years of age!), explains: "When I first started [picking waste] [...] I went to the dumps, I got up at five or six in the morning, before the waste collection truck, to pick [recyclables]. But afterwards, I was afraid of falling down, you see, there is a lot of filth, and I thought 'I will fall down', or the cars that pass by in the street, they almost run me over, and I thought 'no, this is dangerous, this isn't worth it'." (Interview T30, Waste-picker, November 2015). Besides risks to their physical health, recycling traders are also exposed to substantial economic risks, as small business owners bear the cost of innovation and entrepreneurship needed for the recycling sector's success.

While waste-pickers are the first actors to give value to recyclable materials by separating it from domestic waste, small recycling businesses act as a key intermediary between the wastepickers and the recycling industry. Before reaching the recycling industry, recoverable waste has to pass through multiple recycling centres of increasing size, each playing a role in 
processing and transporting recyclable waste to the recycling facilities. The scheme responds to the geographical and physical constraints posed by urban infrastructure. Waste has to be handled in small quantities when it is first produced: this is because as waste is disposed of in the street throughout the day, it has to be collected daily from many small units; and this has to happen in a multitude of small streets. In the case of Tepito, where most streets are mixeduse (houses inside of the blocks and markets on the street) waste is collected from streets where the semi-permanent market stalls do not allow for a collection truck to pass through. In those areas, waste collection and transport is carried out manually. Waste-pickers only collect what they can carry on their back or stack on a small trolley. They then walk to the small recycling centres scattered around the neighbourhood.

The small recycling centre's location has to be close enough to the main mixed-use streets where waste-pickers collect recyclables. Thus, well-located recycling centres require intraurban land usually expensive and small in size. In consequence, they are limited in the amount of recyclables they can handle. Unlike waste pickers, who have to sell what they gather daily, small recycling centres can store bulkier items for a few days to a week, and up to a few months for the less bulky ones (such as copper or bronze). They have machinery adapted to the size of their plot and their storage capacity, such as cardboard compactors to make bales of the adequate weight and volume (between 100 and 600 kilos) to be transported in small pick-up trucks (bigger trailers cannot manoeuvre in these small neighbourhood streets). This means that small recycling centres also rely on intermediaries to sell their waste. Bigger recycling centres provide a service with machinery that is adequate to receive recyclables by hundreds of kilos: their scales, forklifts, and trailers are adapted for these quantities. They are located in industrial areas in the outskirts of the city; no more than $15 \mathrm{~km}$ from the city centre, and with easy access for their providers. ${ }^{6}$

They ultimately sell recyclables to transnational companies that operate all over Mexico (for cardboard and metals) or abroad (for plastics). ${ }^{7}$ These small and big recycling traders make up a network of intermediaries operating at different scales which is necessary for the recycling

\footnotetext{
${ }^{6}$ Given that recyclables are not valuable materials (for instance, PET, which is one of the most expensive plastics, is bought at 3.5 Mexican Pesos per kilo - approximately 0.2 USD -, keeping costs low is the key to the business. The more the recyclables have to be transported, the more they lose added value (due to the cost of transport increasing).

${ }^{7}$ Although the great majority of recycling takes places once the recyclables reach the recycling industry, there is also evidence of small recycling centres processing some recyclables themselves. This is the case with the metal extracted from objects such as radiographies and photo negatives (silver) and electronic appliances (palladium). In some cases, processing (particularly of electronic waste) involves the use of toxic chemicals which are released through burning into the atmosphere, and through dumping in the garbage.
} 
industry to be viable, both in physical and in economic terms (Table 1). Although nonrecyclable waste is disposed of within the metropolitan area, recyclables enter a global market and are exported worldwide (see Figure 5).

Table 1: Scales of waste flows produced in Tepito sells to . .7

\begin{tabular}{|c|c|c|c|c|}
\hline & Waste-pickers & $\begin{array}{l}\text { Small } \\
\text { recycling } \\
\text { centre }\end{array}$ & $\begin{array}{l}\text { Intermediates / big } \\
\text { recycling centres }\end{array}$ & $\begin{array}{l}\text { Recycling } \\
\text { industry }\end{array}$ \\
\hline \multirow{2}{*}{$\begin{array}{l}\text { Approximate } \\
\text { number in... }\end{array}$} & \multicolumn{2}{|c|}{... Tepito } & \multicolumn{2}{|c|}{... the metropolitan area } \\
\hline & One hundred & Twelve & Hundreds & Dozens \\
\hline $\begin{array}{c}\text { Amount of } \\
\text { recyclables sold in } \\
\text { one go }\end{array}$ & Grams or kilos & $\begin{array}{l}\text { Hundreds of } \\
\text { Kilos }\end{array}$ & Tons & $\begin{array}{l}\text { Hundreds of } \\
\text { tons }\end{array}$ \\
\hline Storage facilities & $\begin{array}{l}\text { None, or one's } \\
\text { own home }\end{array}$ & $\begin{array}{c}\text { Intra-city } \\
\text { warehouse, } \\
\sim 100 \mathrm{~m}^{2}\end{array}$ & $\begin{array}{c}\text { Industrial area } \\
\text { warehouse, } \sim 5,000 \\
\text { to } 20,000 \mathrm{~m}^{2}\end{array}$ & $?$ \\
\hline Transport type & $\begin{array}{l}\text { Bags carried on } \\
\text { one's back, or on } \\
\text { trolleys }\end{array}$ & Pick-up trucks & Trailers, train & $\begin{array}{c}\text { Train / Boat } \\
\text { containers, } \\
\text { Trailers }\end{array}$ \\
\hline $\begin{array}{l}\text { Distance travelled } \\
\text { to sell recyclables }\end{array}$ & $100-500 \mathrm{~m}$ & $500 \mathrm{~m}$ to $15 \mathrm{~km}$ & $15 \mathrm{~km}-1000 \mathrm{~km}$ & Worldwide \\
\hline
\end{tabular}

Figure 5: Flows of waste from Tepito to their disposal sites

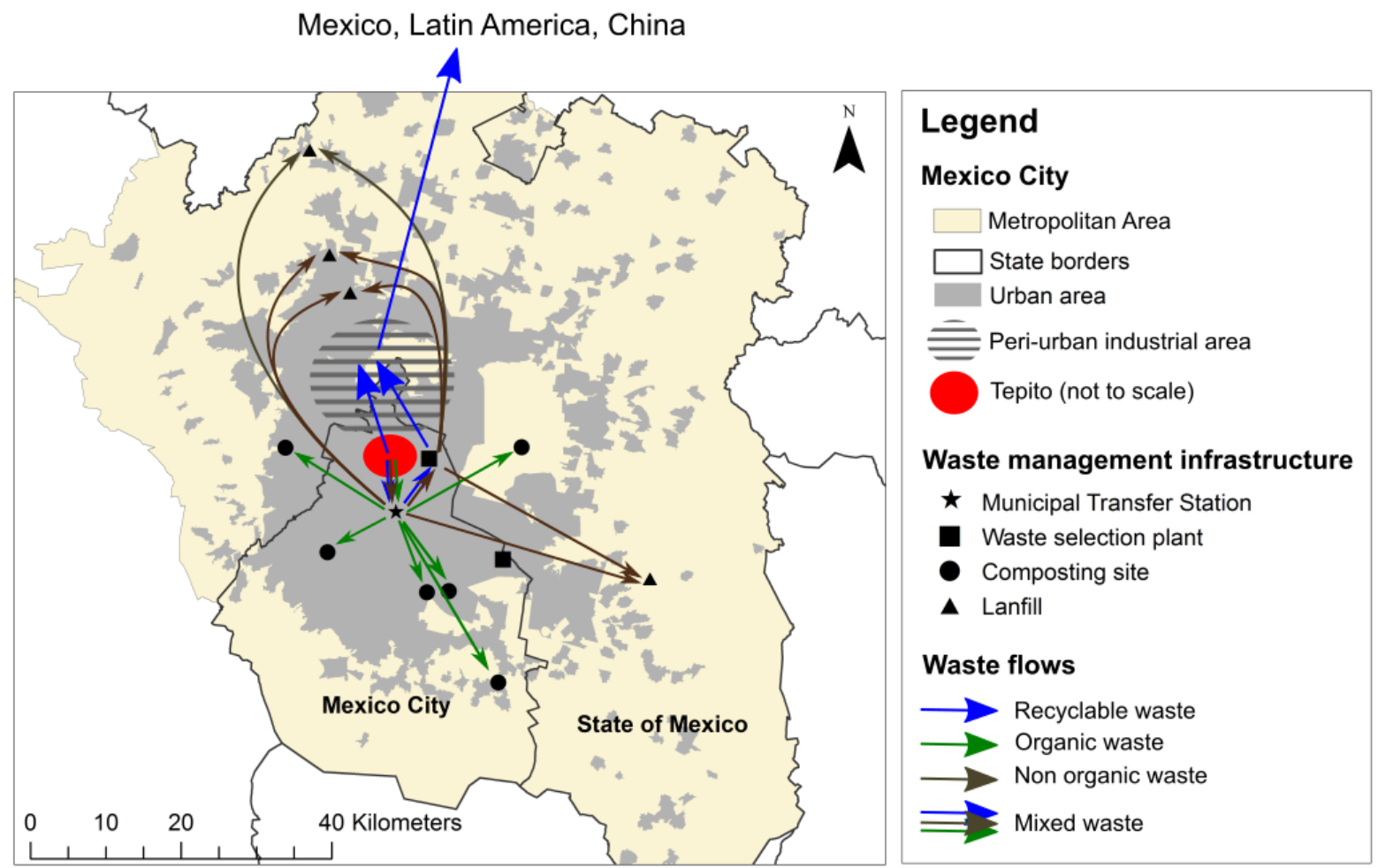


Civil servants are well aware of the role of informal waste handlers as intermediaries in waste management. Interviews with a range of experts (governmental and non-governmental) reveal a consensus that informal workers play an essential role in handling the city's recycling. As one interviewee puts it, "Mexico City must have the highest recycling rate in the world! [...] If you visit a landfill, you will see there is no recyclable material left in the waste, it has all been extracted [by waste-pickers]." (Interview T33, Expert, November 2015). Yet, despite this knowledge, informal workers remain invisible in public discourse and governmental strategies. One illustration of this is that none of the participants in this study has had any sort of contact with civil servants in charge of waste collection or environmental policy, whether a visit to observe the processes, a training programme, a monitoring of toxic waste releases or any sort of institutional support.

We suggest two main reasons for the persisting invisibility of informal workers in public discourse and their exclusion from waste management strategies: first, it helps reproducing the cacique-based system, which perpetuates the system of local chiefs which supports the party in power. Secondly, it removes the governments' responsibility towards informal workers, particularly ensuring they have decent working conditions and pay.

\subsection{Waste management in Santiago de Chile}

In 2014 Santiago metropolitan region produced an estimated of 10,740 tons per day of nonindustrial waste (Valencia, 2015), which represents $1.5 \mathrm{~kg}$ per capita per day. However, waste generation is unequal between urban and peri-urban neighbourhoods, as well as between highincome and low-income populations. For instance, whilst the daily average of waste production in Vitacura, the wealthiest municipality in Santiago, is above $2 \mathrm{~kg}$ per person, in La Pintana, one of the poorest municipalities, it is just below $1 \mathrm{~kg}$. In Colina, this figure is of $1.3 \mathrm{~kg}$ per capita per day (MMA, 2011).

Since the end of the dictatorial regime in 1990, Santiago's waste management system has developed in a context of reforms to tackle down the negative impacts of previous laissez faire neoliberalism and to advance economic growth by regulating the private activity (Sanzana Calvet \& Castán Broto, 2016). Indicators of urban poverty, air pollution, lack of access to basic services, poor road system, housing deficit and collapsing dumps were significantly improved to OECD levels, whilst the construction industry and financial sector benefited from a framework of public-private partnerships and concession schemes (Fernández et al., 2010). 
Waste management, however, is a persistent problem in Santiago de Chile, ${ }^{8}$ worsened by a tendency towards privileging privatisation of urban services that has led to a splintering process, characterised by the concentration of services and economic activities in a minority of rich municipalities (Orellana, 2009).

The metropolis is divided in 56 autonomous municipalities, responsible for providing basic services, including waste management. Post-dictatorship governments seeking waste management improvements focused on stabilising, controlling and ultimately closing dumps and old landfills. Waste management has evolved from a fragmented activity handled by local actors with poor environmental standards, to a regulated market industry at a metropolitan scale, dominated by few large companies with high environmental standards. The waste management system in Santiago incorporates at least three levels: national policies that set standards and goals, regional government control of the development of landfills and municipal management of waste collection.

Since the mid-2000s national policies have led to the opening of privately-operated sanitary landfills in peripheral and peri-urban municipalities and the licensing large private operators (Sabatini \& Wormald, 2004; CONAMA, 2005a). Each municipality in Santiago is free to contract private contractors for each step of the process. This has resulted in two different approaches to municipal waste management: one in which the majority of the metropolitan municipalities -including that of Chicureo- individually contract private operators to manage their waste, resulting in the strengthening of the major private operators; and another in which twenty municipalities from the Southern half of Santiago have formed a private utility company (EMERES) under the mayors' control $^{9}$ to ensure leverage in negotiations with the transfer plant and landfill operators (Vasquez, 2011; CONAMA 2005b). According to a highly ranked ministry official in charge of sustainable construction, this freedom of choice often means that in those metropolitan municipalities lacking capabilities, "smart mayors will avoid as much as possible to be involved in waste management: a private collector is hired and the waste is thrown to a landfill” (Interview C9, State official, December 2012). The recycling of residential waste does not take place as part of municipal waste management. Instead, this is an activity carried out by several actors along the formal/informal continuum. Traditionally,

\footnotetext{
${ }^{8}$ For instance, and despite significant improvements, in 2014 no less than 65 illegal small landfills and nearly 600 micro-dump sites were reported in the metropolitan area ("Santiago tiene 65 vertederos no autorizados", 2015). ${ }^{9}$ Although the company was formed in the 1980s, it was relaunched in 2010 under control of these municipalities when the mayors refused to renew the contracts with the largest private waste operator (Fajardo, 2015; Fernández, Avendaño, \& Schüler, 2010).
} 
there have been three types of actors: informal waste pickers or cartoneros ${ }^{10}$ are in charge of the collection and primary selection of materials from the streets and dumps ${ }^{11}$; while private companies and charities stock, transport, reduce and refine materials, and medium to large industries recycle or reuse the materials. Municipalities have also tested initiatives to control the recycling chain, such as the late 2000s pilot program of a network of 'clean spots' collection points for domestic recyclables managed by private contractors- in one the wealthiest municipalities of Santiago, which has been replicated in other upper income municipalities (Rojas, 2013).

\subsection{Tracking waste flows in the enclaves of Chicureo}

The diagram of Chicureo's waste flows is depicted in Figure 6, and represented spatially in Figure 7. Informal waste flows include the composting of garden organic waste in households' own gardens, the illegal disposal of garden organic waste or small-scale construction debris by trucks operators hired by households or small contractors, and the dumping of garden organic waste to canals in the enclaves and their surrounding areas. Private operators are responsible for the often illegal (and unaccounted) disposal of organic and construction waste. Although private utility companies manage waste, the municipality is accountable because the bids for concession are decided by elected authorities; the municipal and metropolitan levels of government have some tools for supervising and controlling the performance of the private actor (even if these are not often used); and the amount and destination of waste flows are registered by governmental agencies and can be accessed by the general public. In contrast, there are no legal accountability requirements for the actions of the private sector (either formal or informal) outside the municipal system and information is given under the basis of voluntary disclosure by private actors, most of the times for public relations and marketing purposes.

Figure 6. Diagram of waste flows produced in Chicureo.

\footnotetext{
${ }^{10}$ Spanish for cardboard pickers, urban poor individuals and groups who gather recyclable materials as paper, glass, cardboard, Tetra Brik, plastic PP, PE, PET and aluminium drink cans.

11 The cartoneros in Santiago have a strong culture of associativity, forming hundreds of small cooperatives, unions or associations and often receiving support from municipal authorities and NGOs (Giovannini, 2014; ILO, 2013). Chilean parliament currently discusses a law promoting recycling, formalising the cartoneros' activity as base recyclers in the fast-growing Chilean recycling industry (MMA, 2015).
} 


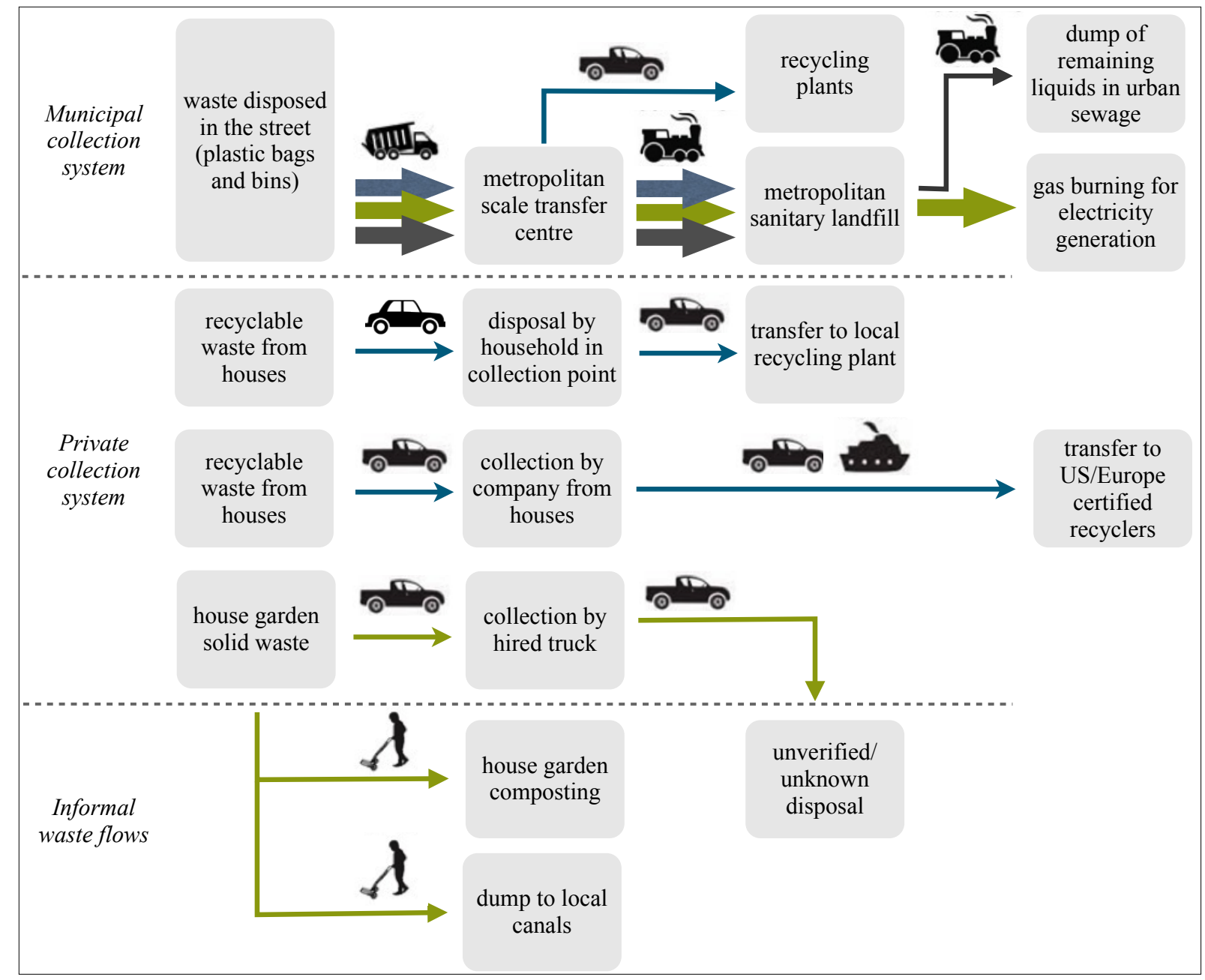

Legend:
Recylcable waste
Organic waste/garden refusal
Non-recyclable waste

Figure 7: Flows of waste from Chicureo to their disposal sites 


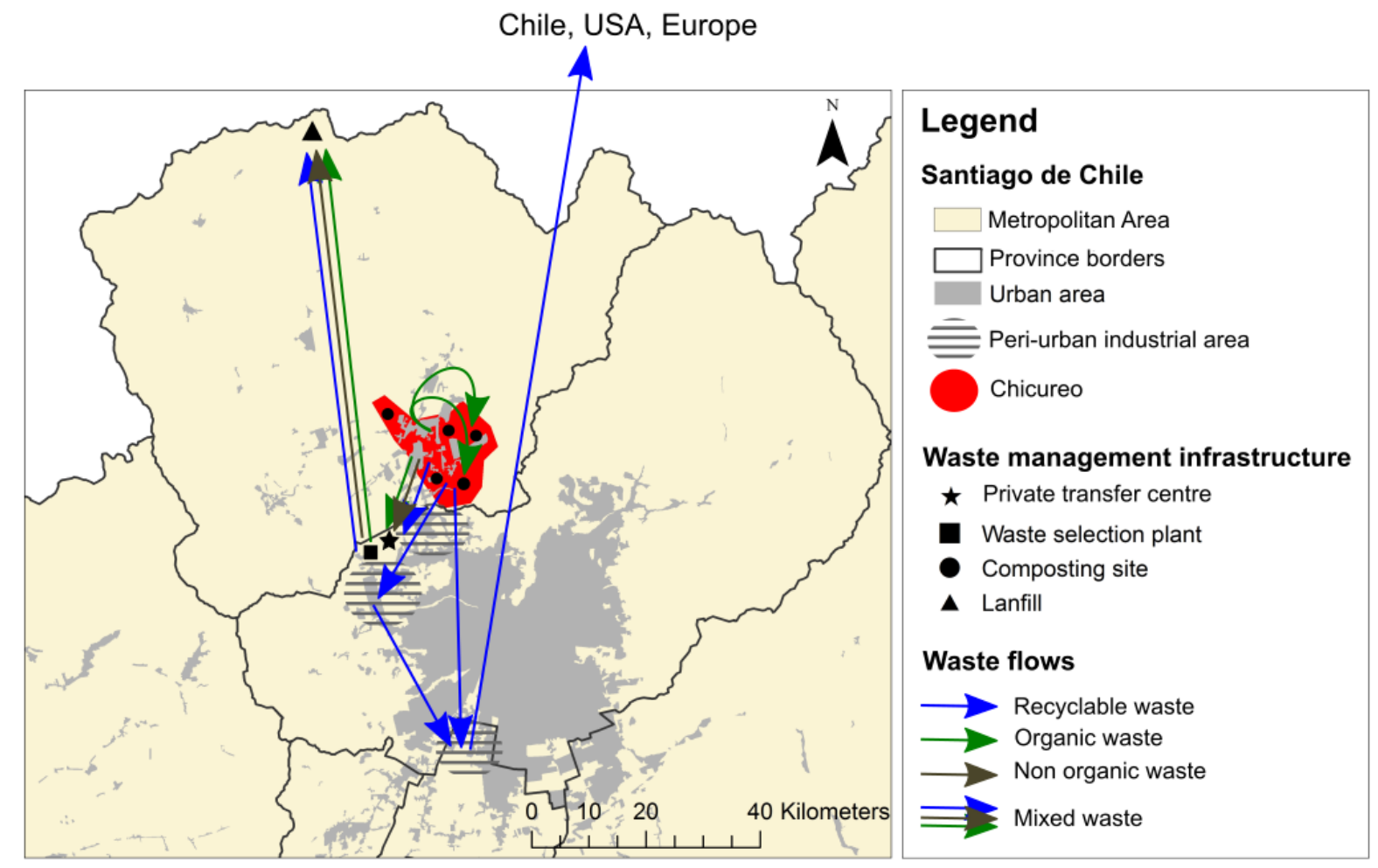

In Chicureo, the municipality has contracted KDM, a firm controlled by foreign investors, which is the largest waste management operator in Santiago Metropolitan Region. This company manages the waste of twenty-four municipalities, accounting for an estimated fiftynine percent of the total volume of metropolitan waste (Pizarro \& Jara, 2015). Chicureo's domestic waste is collected by KDM's local operator from the enclaves' streets and transported to KDM's transfer plant in another municipality, where some recyclable materials are extracted and the refuse is compacted. The transfer plant receives 850 trucks per day, and dispatches eight to ten daily rail convoys carrying each 700 tons of municipal waste to be disposed of in the 220 hectares of a sanitary landfill in the Til Til municipality ${ }^{12}$ (KDM, 2014). Since 2010, part of the waste is used to produce biogas and subsequently transformed in electricity on the landfill site, while the rest is buried. The organic liquids produced in the process are treated in the landfill and sent back to Santiago by the same rail line, where they are discharged into the sewage system (Chileresiduos, 2014). The sewage ends in a treatment plant that also produces biogas for residential and industrial uses in Santiago (Aguas Andinas, 2013), what a Chilean scholar depicts as a new "virtuous circle" in urban sustainability (Interview C1, Scholar, December 2012). A usual presence in Santiago's urban landscape, cartoneros are not allowed

\footnotetext{
12 Overall, waste generated in Chicureo is transported by truck $16 \mathrm{~km}$ to the transfer plant and $67 \mathrm{~km}$ by rail to the landfill.
} 
to operate inside Chicureo's developments, and charity managed disposal bins have not been reported by our fieldwork. In contrast, private companies ${ }^{13}$ hired by enclave developers and managers collect recyclables (such as paper, cardboard, drink cans and plastic) from 'clean spots' located inside the enclaves and transfer them further to recycling plants or even to international plants ${ }^{14}$ ("Disminuyen basura electrónica", 2015). Thus, as a voluntary activity, recycling in Chicureo relies mostly on households' willingness to pre-select the waste and transport it to a 'clean spot'. Residents interviewed have complained of this for-profit scheme as too time- and work- consuming, whilst they feel a total lack of transparency on "who wins" with it (Interview C23, Resident, March 2013; Interview C33, Resident, April 2013). As the manager of an enclave has revealed, the rate of use of recycling facilities in that neighbourhood is still low: "only 10 to 20 per cent of the residents do use it. All the other waste is collected by the municipal truck” (Interview C15, Developer, January 2013). Despite these numbers, this private recycling scheme plays a crucial role as a 'green' attribute in both the property developers' public discourses and the enclaves marketing, where enclaves are presented as examples of successful green waste management and the residents as individuals committed to environmental sustainability (Bañados, 2013). Chicureo's recycling chain combines large private operators for collection, transfer and deposit with rather small scale specialised recycling companies (Table 2).

Table 2: Scales of waste flows produced in Chicureo

\begin{tabular}{|c|c|c|c|c|c|}
\hline & $\begin{array}{l}\text { Waste- } \\
\text { pickers }\end{array}$ & $\begin{array}{c}\text { Solid waste } \\
\text { utility }\end{array}$ & $\begin{array}{l}\text { Small } \\
\text { recycling } \\
\text { facility }\end{array}$ & $\begin{array}{l}\text { Intermediates / } \\
\text { large recycling } \\
\text { centres }\end{array}$ & $\begin{array}{l}\text { Recycling } \\
\text { industry }\end{array}$ \\
\hline \multirow{2}{*}{$\begin{array}{c}\text { Estimated number } \\
\text { in... }\end{array}$} & \multicolumn{3}{|c|}{... Chicureo } & \multicolumn{2}{|c|}{...Metropolitan Santiago } \\
\hline & None & One & Two & Tens & Dozens \\
\hline $\begin{array}{c}\text { Amount of } \\
\text { recyclables traded } \\
\text { monthly }\end{array}$ & - & - & Tons & Tens of Tons & Hundreds of tons \\
\hline Storage facilities & - & 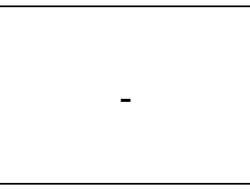 & $\begin{array}{l}\text { Local storage } \\
\text { in bins } \\
\sim 50 \mathrm{~m} 2\end{array}$ & $\begin{array}{l}\text { Industrial area } \\
\text { warehouse, } \sim \\
5,000 \text { to } 20,000 \\
\text { m2 }\end{array}$ & $?$ \\
\hline Transport type & - & Garbage truck & Pick-up trucks & Truck, trailer & Trailers / Ship \\
\hline $\begin{array}{c}\text { Distance travelled } \\
\text { to next recycling } \\
\text { station } \\
\end{array}$ & - & $16 \mathrm{~km}$ & $20 \mathrm{~km}$ to $35 \mathrm{~km}$ & $20 \mathrm{~km}-60 \mathrm{~km}$ & Worldwide \\
\hline
\end{tabular}

13 The TriCiclos company manages the clean spots in the enclaves of Santa Elena since 2010 and Piedra Roja since 2011.

${ }^{14}$ As reported by E-waste Recycling Co. operating in Chicureo since 2014. 
Figure 7. 'Clean spot': empty recycling facilities in an urban enclave in Chicureo

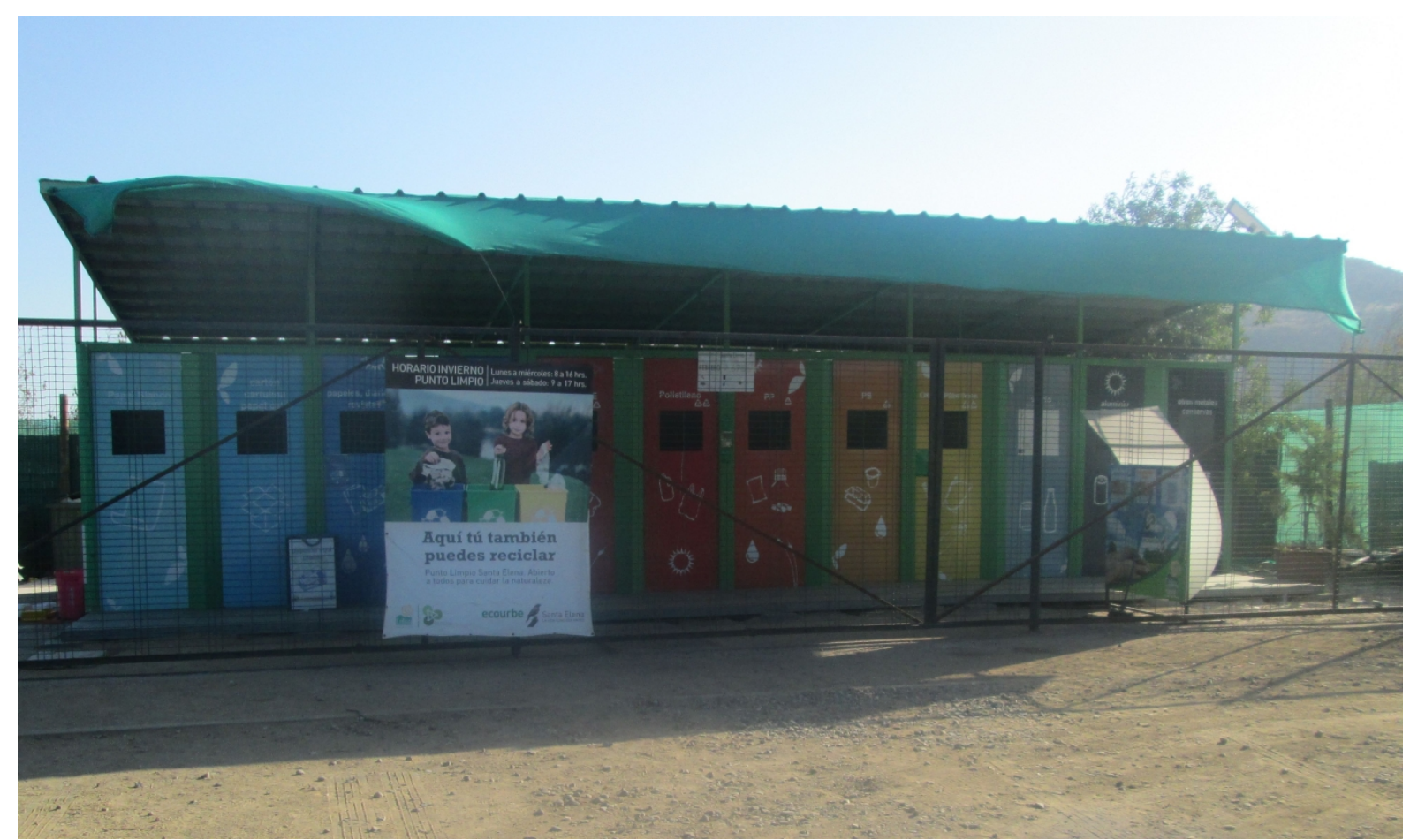

Credits: Martin Sanzana Calvet, April 2013.

Organic waste (mainly food and gardening refuse) is estimated to be a significant portion of domestic waste in Santiago, above fifty percent of its total volume (CONAMA, 2010). In the municipal system, organic waste ends in sanitary landfills. However, Chicureo enclaves have additional strategies to manage their organic waste, whether this is through its removal or disposal in situ. In the first case, residents or condominium managers hire trucks -informal contractors- to collect and dispose of gardening refuse, although the ultimate destination is unclear, as some of this garden waste ends up in illegal landfills, micro dumps in the municipality or anywhere in the metropolitan region, as acknowledged by residents of allotments condominiums in interviews. The in situ disposal follows three modalities: the composting of organic waste; the illegal burning of gardening refuse; and the dumping of gardening refuse (alongside construction debris) in the irrigation canals around the condominiums allotments. This informal management of organic waste has a significant impact on the amount of waste generation in Chicureo that is recorded in official statistics: using a range of municipal data, the daily per capita production of waste in Chicureo can be estimated 
to be just below $0.8 \mathrm{~kg}^{15}$ (Municipalidad de Colina, 2013; Valencia, 2014). This surprisingly low average problematically hides the differences between organic waste management in the developments with more rural features (such as larger plots) and those of the recent wave of 'suburban-style' enclaves where organic waste goes to the municipal bin.

The green credentials of Chicureo are displayed in clean streets and common areas whereas the disposal and treatment of a substantial part of its waste is externalised to less privileged peri-urban areas within the metropolitan region. The system of private contractors also means high costs of waste management for the municipality: in 2014, waste management represented the third highest individual item in Colina's annual municipal budget (seven percent) (SINIM, 2015). The potential income associated with waste management, such as the sale of recyclable materials, the production of gas or the sale of carbon bonds is captured by private contractors. Private companies' incentives to increase the volume managed by signing as many long-term contracts with municipal governments as possible (Pizarro \& Jara, 2015) seem to have fostered corrupted practices, with prosecutions of municipal staff (including mayors) involved in shady waste management deals (Urquieta, 2013; Fernández et al, 2010).

The ban of the cartoneros and the monopoly of private contractors over recycling streams also seems very far from reaching optimum efficiency, despite the enthusiasm displayed by enclave developers in promoting their recycling schemes as examples of greener or ecological neighbourhoods. The head of the Chilean property developers' association explains that efficiency rates of the municipal and private schemes are below those of the cartoneros. The KDM transfer plant in Santiago reports a recycling rate of two percent of the total volume of waste processed there ${ }^{16}$ (KDM, 2014), whilst the 'clean spots' contribute to recycling only 3.7 percent of the 691 tons of domestic waste produced in the enclaves in $2012 .{ }^{17}$ In contrast, cartoneros' activity is estimated to reduce municipal solid waste by up to twelve percent in Santiago's municipalities where they operate (CONAMA 2005b).

\subsection{Cases comparison}

The waste flows diagram of Tepito and Chicureo illustrate different patterns of waste management: the case of Tepito indicates the dynamism and capillarity of the local metabolism,

\footnotetext{
${ }^{15}$ Domestic solid waste collected daily in Chicureo by municipal contractors amounts to $23,033 \mathrm{~kg}$, for nearly 30,000 inhabitants.

${ }^{16}$ As a comparison, only three of thirty-two European countries (considered in this study) have a municipal waste recycling rate lower than 4\% (EEA, 2010). In 2012/2013, "recycling rates in local authorities across England range between $12 \%$ and $67 \%$ " (Parliament, 2014)

17 Own estimation based on data from Municipalidad de Colina (2013); Buena Salud (2013).
} 
in which waste is collected and partly processed locally by many actors before leaving the neighbourhood, and is then disposed of in the metropolitan area and beyond. On the other hand, in the case of Chicureo both the management system and the high standard transport infrastructure lead to a fast circulation of non-organic waste to other metropolitan sites to be transformed and disposed of. In both cases, the circuits of waste management connect local, metropolitan and global scales while blurring municipal boundaries (see Table 3).

Table 3. Scales and flows of waste in Tepito and Chicureo

\section{Tepito (Mexico City)}

Chicureo (Santiago)

\begin{tabular}{lcc}
\hline $\begin{array}{l}\text { System } \\
\text { control }\end{array}$ & $\begin{array}{c}\text { Weak over all scales; dispersed } \\
\text { between actors and administrative } \\
\text { powers }\end{array}$ & $\begin{array}{c}\text { Strong when concentrated in chain of large } \\
\text { private utilities; weak and dispersed in } \\
\text { small private contractors and recyclers }\end{array}$ \\
\hline Local scale & $\begin{array}{c}\text { Massive collection of recyclables; } \\
\text { diversity of facilities for local } \\
\text { sorting and primary recycling } \\
\text { process }\end{array}$ & $\begin{array}{c}\text { Collection in few trucks, fast exporting } \\
\text { waste outside the district; few small } \\
\text { recycling facilities for storage and transfer } \\
\text { only; local organic composting }\end{array}$ \\
\hline $\begin{array}{l}\text { Metropolita } \\
\text { n scale }\end{array}$ & $\begin{array}{c}\text { Disposal of non-recyclable waste } \\
\text { in multiple sites, recycling } \\
\text { processing in industrial areas }\end{array}$ & $\begin{array}{c}\text { Chain of recycling and disposal } \\
\text { concentrated in one circuit of collection- } \\
\text { transfer-disposal and one narrow circuit of } \\
\text { recycling }\end{array}$ \\
\hline
\end{tabular}

Globalisatio n Export of recyclables
Recyclable exports (small recycling industry); national industrial supply (large recycling industry)

\begin{tabular}{lcc}
\hline $\begin{array}{l}\text { Role of local } \\
\text { boundaries }\end{array}$ & $\begin{array}{c}\text { Local boundaries set by waste } \\
\text { handlers (and their transport } \\
\text { capacity) }\end{array}$ & $\begin{array}{c}\text { Local boundaries blurred by focus on fast } \\
\text { waste extraction }\end{array}$ \\
\hline Reuse & Local reuse & Not observed \\
\hline Reduce & Local reduction & Metropolitan scale infrastructures \\
\hline Recycle & Local recycling and processing & $\begin{array}{c}\text { Transfer of recyclables to metropolitan } \\
\text { sites }\end{array}$ \\
\hline Disposal & $\begin{array}{c}\text { Metropolitan landfills and illegal } \\
\text { dumping sites }\end{array}$ & $\begin{array}{c}\text { Mostly in one metropolitan energy- } \\
\text { producing landfill; some locally in illegal } \\
\text { dumping sites }\end{array}$
\end{tabular}

In many aspects, the cases of Tepito and Chicureo may appear as opposites, one showing the dominance of the informal popular economy in a consolidated, low-income central district of Mexico City, and the other stressing the dominance of the large-scale private sector in a new peri-urban upper income zone of Santiago de Chile. However, both show a continuum of weaknesses on the part of public entities, and particularly at the municipal level, which is the one in charge of waste collection services (Table 4). These weaknesses have different causes: 
in Tepito, it is imposed by the vitality of the informal economy and the self-governing capacity of local citizens. In Chicureo, it is explained by the strength of large-scale capitalist actors and the state pro-growth and privatisation policies. In both cases the municipal sector is financing waste collection services, however it has little control over the waste management process, nor does it share the benefits from the recycling activities carried out by private and nongovernmental actors.

Table 4. Governance of waste in Tepito and Chicureo

Tepito (Mexico City)

Chicureo (Santiago)

\begin{tabular}{ccc}
\hline $\begin{array}{c}\text { Origin of waste } \\
\text { flows }\end{array}$ & $\begin{array}{c}\text { Commerce and residential } \\
\text { (interior) }\end{array}$ & $\begin{array}{c}\text { Residential (interior and garden), } \\
\text { commerce and construction }\end{array}$ \\
\hline $\begin{array}{c}\text { Role of } \\
\text { informal actors }\end{array}$ & $\begin{array}{c}\text { Collection of recyclables and } \\
\text { primary recycling }\end{array}$ & $\begin{array}{c}\text { Collection and disposal of organic waste } \\
\text { (garden refuse) }\end{array}$ \\
\hline $\begin{array}{c}\text { Role of } \\
\text { residents }\end{array}$ & Waste separation and disposal & $\begin{array}{c}\text { Waste separation and disposal; disposal } \\
\text { of recyclables in facilities; managing } \\
\text { garden refuse }\end{array}$ \\
\hline
\end{tabular}

\begin{tabular}{ccc}
\hline $\begin{array}{c}\text { Role of } \\
\text { municipality }\end{array}$ & $\begin{array}{c}\text { Collection and transfer of solid } \\
\text { waste }\end{array}$ & Financing waste utility services \\
\hline $\begin{array}{c}\text { Role of private } \\
\text { companies }\end{array}$ & Recycling & $\begin{array}{c}\text { Collecting and transferring solid waste; } \\
\text { collecting and transferring recyclables }\end{array}$ \\
\hline $\begin{array}{c}\text { Ongoing } \\
\text { reconfiguration }\end{array}$ & $\begin{array}{c}\text { Waste pickers are increasing } \\
\text { their participation in recycling } \\
\text { processes }\end{array}$ & $\begin{array}{c}\text { Waste management industry is adopting } \\
\text { technological advancements to better } \\
\text { recycle and produce energy in landfills }\end{array}$ \\
\hline Synergies & $\begin{array}{c}\text { Waste pickers and small } \\
\text { recycling centres boost local jobs }\end{array}$ & $\begin{array}{c}\text { Private utilities focus on domestic waste } \\
\text { while private companies collect } \\
\text { recyclables }\end{array}$ \\
\hline Conflicts & $\begin{array}{c}\text { Ownership of recyclables } \\
\text { between waste pickers and } \\
\text { municipal collection service }\end{array}$ & $\begin{array}{c}\text { Illegal dumping of garden refuse } \\
\text { produces pollution of local water canals } \\
\text { and micro dumping sites }\end{array}$ \\
\hline
\end{tabular}

The dominance of non-governmental actors is striking, as is the variety of intermediary roles that they play- whether they are small or large-scale companies, formal or informal, organised or independent. While in Tepito, informal waste handlers play an essential role in increasing recycling rates; in Chicureo informal management of organic waste by households and informal refuse services seems to have a significant impact in reducing the per capita volume of waste collected by the municipal system. Yet their role remains unaccounted for and constrained in different ways.

In Tepito, despite positive impacts of non-governmental actors in the recycling process, and regular cooperation and communication between them and municipal workers, there is no official support of waste handlers by the public sector to reduce the risks associated to their 
work; rather, the relationship remains governed by local practices of clientelism. Additionally, large industrial recyclers also rely on informal workers as a source of cheap, efficient and flexible labour - achieved precisely because of the waste handlers' informal status. Informal workers' participation in waste management activities is restrained to the least lucrative and most dangerous ones, particularly waste-picking.

In Chicureo, recycling activities have developed as a premium niche, whereby developers increase the market value of their condominiums, houses and plots by greenwashing their image, and companies cream-skim the valuable recyclable waste of the enclave residents. The traditional waste pickers (the cartoneros), whose presence may menace the elitist image of the enclaves, and who may compete for valuable waste, are excluded from waste management activities, although there is room for private informal contractors to manage minor garden and construction refuse. This exclusion is made possible by the physical characteristics of new urbanisation patterns (gated communities with restrained physical access).

We observe that long-term political processes impact the legitimacy of different waste workers and the role they are allowed to play in waste management: in Mexico City, historical relations of caciquism inherited from the early 20th century Mexican single-party politics maintain informal workers in particular roles within the waste management system (namely, performing the least paid and most dangerous tasks). On the other hand, in Santiago de Chile, the trend towards neoliberalisation inherited from the dictatorship period explains the primordial role given to the private sector in providing waste management services, and its power to exclude the cartoneros. Thus, while the process of "normalisation of informality" (as described by Oteng-Ababio, 2011) is clearly taking place in Tepito, where informal actors are increasingly integrated in a globalised commodity chain of recyclable materials, this trend has not been observed in Chicureo, where multinationals are expanding their activities to all steps of waste management, including those which are the base of the cartoneros' livelihood.

This configuration of waste flows poses questions of environmental justice: while informal waste handlers play a key role in waste management and have the capacity to reduce environmental burdens by processing and recycling waste; they also bear the most risk associated with processing waste. Risks to their physical health and well-being are well illustrated in the case of Tepito; where waste-pickers suffer from bites and cuts from opening domestic garbage bags. On the other hand, the case of Chicureo exemplifies the existence of structural risks to the workers' livelihood, which is constantly put at risk; the mere presence of informal waste-pickers being a risk to the economical dynamics of enclave urbanisation. 


\section{$\underline{\text { 6. Discussion and conclusions }}$}

Our engagement with urban metabolism has a specific objective (finding avenues for politicising material flows analysis), but it also engages with a broader question about the relevance of engineering and other technical methods to support analyses of urban inequality and environmental injustice. We seek to develop an ethos of critical engagement with knowledge production in relation to resources in the city. In the case of urban metabolism, this means questioning key assumptions related to the notions of system boundaries and flows.

In terms of the system boundaries, we have advocated opening the "black box" of the city and looking at patterns of waste management in a multi-scalar way. This means moving away from arbitrary definitions of the city as an administrative unit, which do not necessarily relate to the patterns of resource distribution (although they can influence them). There are different ways in which the idea of system boundaries can be reframed to engage with flows (e.g. studying the distant connections of resources that maintain cities, examining exchange processes in its hinterland; following value chains). In this case, we have chosen to examine urban metabolic flows as they relate to the experiences of ordinary citizens in the city. This has framed our research approach by setting a strong focus on fieldwork and on-the-ground observations, rather than on existing datasets.

Making our analysis multi-scalar (rather than setting rigid system boundaries around the urban system) reveals an assemblage of local, metropolitan and global dynamics that shape cities' waste metabolisms; and particularly, how formality and informality are interwoven in waste management in specific locations. For instance in the case of Santiago de Chile, a neighbourhood-scale is necessary to document the presence (or absence) of informal recyclers. How these workers enter the waste cycle, the efficiency they achieve and the barriers they encounter vary greatly among neighbourhoods, and thus could hardly be explored at an urban scale. Likewise in Tepito, the recycling chain is constituted of varied local practices interconnected to wider processes of waste and resource circulation. This case significantly displays how a very territory-specific informal labour force finds its way into the global recycling industry.

The analysis of the metabolic configuration of waste in Tepito and Chicureo demonstrates how waste flows trespass both institutional and geographical boundaries, resulting in interconnected layers of urban infrastructure, services and land use. In the making of the production-circulation-transformation-disposal cycle of waste, different actors and processes are assembled, resulting in a system in which the measurement of the efficiency of each part could not account for the sustainability of the whole. This pattern of heterogeneous actors 
working alongside in the provision of waste management services (not unlike the "modernised mixtures" described by Scheinberg et al. (2011)) is visible in both cities, albeit embedded in very different political and material contexts. This suggests that analyses of waste management which assume that state and private sector manage waste by formally entering clear and identifiable agreements in well delimited areas are likely to fail to explain how waste management actually happens. Official statistics will be extremely limited to reflect upon the actual flows - and provide any solutions - as long as some actors remain excluded from the data creation process. Crucially, there has to be space within Industrial Ecology to question which actors are relevant and legitimate for the study of material flows; and to investigate their role in producing and transforming those flows. In the case of waste management, some of those "forgotten actors" appear to be informal waste handlers and private contractors.

With regards to the concept of flows, we argued in favour of a flexible approach focusing particularly on the intricate relationship between waste flows, the actors that enable them and the re-configurations of power they operate. To do so, we move away from quantification efforts, thinking instead of flows in relation to their insertion in the urban fabric. Specifically, we do that through documenting qualitatively the role of different waste handlers, to reveal the multi-scalar, and changing, structure of waste flows that conform a city's metabolism. This approach allows us to identify the range of intermediaries, both in Tepito and Chicureo, which make recycling and other waste management practices possible. Documenting the experiences of different levels of intermediation is a means to reveal the complex stages of waste management and the risks they pose to the people who manage such stages, something which is hardly acknowledged in formal waste management systems.

We advocate a political approach to material flows research which engages with qualitative and place-based analyses. However, we also acknowledge the value of quantitative metabolism research. For example, the recognition of the role of informal workers in waste management may also depend on their inclusion in quantification exercises. Yet, quantification cannot be done with reference to an abstract conceptualisation of waste flows and system boundaries which does not recognise that, ultimately, people are maintaining those flows. Methodologies such as material flows analysis will be most relevant to understanding the urban fabric when they are applied alongside a critical analysis of common held assumptions, or doxa; particularly those embedded in the production of the statistics underpinning conventional urban metabolism analysis. The methods emerging from Industrial Ecology to analyse material flows are a helpful tool to carry out these exercises; however, it is necessary to acknowledge that the way these are framed -which flows are included and which are not- is also political. 


\section{Acknowledgements:}

The authors wish to thank the anonymous reviewers for their valuable feedback. 
Bibliography:

Acurio, G., Rossin, A., Teixeira, P. F., \& Zepeda, F. (1997). Diagnóstico de la situación del manejo de residuos sólidos municipales en América Latina y el Caribe. Inter-American Development Bank.

Ahmed, S. A., \& Ali, M. (2004). Partnerships for solid waste management in developing countries: Linking theories to realities. Habitat International, 28, pp.467-479.

Ali, M., Olley, J., Cotton, A. (1999) Public sector delivery of waste management services: Cases from the Indian Sub-Continent. Habitat International. 23(4), pp.395-510

Aguas Andinas (2013). Aguas Andinas y Metrogás inauguran planta de de biogas. Retrieved 12-11-2015 in https://www.aguasandinas.cl/noticias/novedades/aguas-andinas-ymetrogas-inauguran-planta-de-biogas

Alfonso Piña, W. H., \& Pardo Martínez, C. I. (2013). Urban material flow analysis: An approach for Bogotá, Colombia. Ecological Indicators.

Bañados, A. (2013, February 03) Puntos limpios se expanden y multiplican en proyectos. El Mercurio, Clasificados Propiedades pp.1,3.

Barles, S. (2009). Urban Metabolism of Paris and Its Region. Journal of Industrial Ecology, 13(6), 898-913. doi:10.1111/j.1530-9290.2009.00169.x

Beall, J. (1997). Thoughts on poverty from a South Asian rubbish dump: gender, inequality and household waste. IDS Bulletin, 28(3), 73-90.

Benson, E. (2014). Informal and Green? transition to a green economy. IIED discussion Paper

Bhuiyan, S. (2010) A crisis in governance: Urban solid waste management in Bangladesh. Habitat International. 34(1), pp.125-133

Brenner, N., Peck, J., \& Theodore, N. (2010). Variegated neoliberalization: geographies, modalities, pathways. Global networks, 10(2), 182-222.

Brunner, P., \& Rechberger, H. (2004). Practical Handbook of Material Flow Analysis. CRC Press.

Cámara de Diputados del Congreso de la Union (2015). Ley General para la Prevención y Gestión Integral de los Residuos - Texto vigente. Diario Oficial de la Federación, retrieved online, 25-07-2016 from:

http://www.diputados.gob.mx/LeyesBiblio/pdf/263_220515.pdf

Castán Broto, V., Allen, A., Rapoport, E. (2012). Interdisciplinary Perspectives on Urban Metabolism. Journal of Industrial Ecology, 16(6), pp.851-861

Castán Broto, V. (2013). Symbolic Violence and the Politics of Environmental Pollution Science: The Case of Coal Ash Pollution in Bosnia and Herzegovina. Antipode, 45(3), pp. 621-640

Castillo Berthier, H. (1984). El basurero - Antropologia de la miseria. Mexico City: Editores Asociados Mexicanos.

Castillo Berthier, H. (2003). Garbage, work and society. Resources, Conservation and Recycling, 39(3), 193-210.

Centro Mario Molina. (2014). Programa de Acción Climática Ciudad de México 2014-2020. Mexico City. 
Chi, X., Streicher-Porte, M., Wang, M. Y. L., \& Reuter, M. (2011). Informal electronic waste recycling: a sector review with special focus on China. Waste Management, 31(4), pp.731-42.

Chileresiduos (2014) Disposición de residuos. Retrieved 12-11-2015 from $\mathrm{http}: / /$ www.chileresiduos.cl/index.php?id=197

CONAMA (2005a). Política de gestión integral de residuos sólidos. Comisión Nacional de Medio Ambiente. Retrieved 13-010-2015 in http://www.sinia.cl/1292/articles26270_pol_rsd

CONAMA (2005b) Sistemas de reciclaje. Estudio de casos en la región Metropolitana. CONAMA Metropolitana de Santiago. Retrieved 28-10-2015 in $\mathrm{http}: / / w w w . s i n i a . c 1 / 1292 /$ articles-31679_Estudio_de_casos.pdf

CONAMA (2010). Primer reporte del manejo de residuos sólidos en Chile. Comisión Nacional de Medio Ambiente. Retrieved 23-11-2015 from http://www.sinia.cl/1292/articles-49564_informe_final.pdf

Cook, I., Swyngedouw, E. (2012). Cities, Social Cohesion and the Environment: Towards a Future Research Agenda. Urban Studies, 49(9), pp.1959-1979

Costa Leite, L. E. (1997). Modelos de privatización del manejo de residuos sólidos urbanos en América Latina.

Dear, M. (2005). Comparative urbanism. Urban Geography, 26(3), 247-251.

Delgado Ramos, G. C., Campos Chávez, C., \& Rentería Juárez, P. (2012). Cambio Climático y el Metabolismo Urbano de las Megaurbes Latinoamericanas. Hábitat Sustentable, 2(1), 2-25. Retrieved from http://remaderas.ubiobio.cl/ojs/index.php/arquitec/article/viewArticle/378

Delgado Ramos, G. C. (2014). Ecología política del metabolismo urbano y los retos para la conformación de ciudades de bajo carbono - Una lectura desde America Latina. Critica Y Emancipación, VI(12), pp.149-174.

Demaria, F., Schindler, S. (2015). Contesting Urban Metabolism: Struggles Over Waste-toEnergy in Delhi, India. Antipode, 28(2), pp.293-313

Disminuyen basura electrónica con nueva campaña de reciclaje integral a domicilio en Piedra Roja. (2015, September 22). El Mercurio. Retrieved 12-10-2015 from http://www.propiedades.emol.com

EEA (2010). Municipal waste recycling rates in 32 European countries, 2001 and 2010. Retrieved 09-06-2015 from http://www.eea.europa.eu/data-and-maps/figures/municipalwaste-recycling-rates-in

Ezeah, C., Fazakerley, J., Roberts, C. (2013) Emerging trends in informal sector recycling in developing and transition countries. Waste Management, 33(11), pp. 2509-19

Fajardo, D. (2015). Municipios crean nuevo modelo de gestión de resíduos. Retrieved 25-72016 from http://www.hubsustentabilidad.com/municipios-crean-nuevo-modelo-degestion-de-residuos/

Fernández, B., Avendaño, F. and Schüler, U. (2010). Negocio de la basura: cuestionado contrato amarra a KDM con 22 comunas de Santiago hasta 2027. Ciper Chile. Retrieved from http://ciperchile.cl/2010/02/25/negocio-de-la-basura-cuestionado-contrato-amarraa-kdm-con-22-comunas-de-santiago-hasta-2027/

Forkes, J. (2007). Nitrogen balance for the urban food metabolism of Toronto, Canada. 
Resources, Conservation and Recycling, 52(1), 74-94.

doi:10.1016/j.resconrec.2007.02.003

Frykman, C. (2006). The Power of Waste - A Study of Socio-Political Relations in Mexico City's Waste Management System. Masters' dissertation. Uppsala University.

Giovannini, M. (2014). From Popular Economy to Social and Solidarity Economy: The Case of Waste Pickers in Santiago de Chile. Euricse Working Papers 73(14). Retrieved from http://papers.ssrn.com/

Gobierno del Distrito Federal (2010). Programa de Manejo Integral de Residuos Solidos del Distrito Federal.

Goldstein, B., Birkved, M., Quitzau, M.-B., \& Hauschild, M. (2013). Quantification of urban metabolism through coupling with the life cycle assessment framework: concept development and case study. Environmental Research Letters, 8(3), 035024. doi: $10.1088 / 1748-9326 / 8 / 3 / 035024$

Graham, S., \& Marvin, S. (2001). Splintering Urbanism - networked infrastructures, technological mobilities and the urban condition. Oxon: Routledge.

Grant, R., \& Oteng-Ababio, M. (2012). Mapping the Invisible and Real "African” Economy: Urban E-Waste Circuitry. Urban Geography, 33(1), pp.1-21.

Guibrunet, L., \& Castán Broto, V. (to be published in 2016). Towards an urban metabolic analysis of the informal city. In K. Archer \& K. Bezdecny (Eds.), Handbook of Cities and Environment. Edward Elgar.

Guy, S., Marvin, S., Medd, W., Moss, T. (2011) Shaping Urban Infrastructures Intermediaries and the Governance of Socio-technical Networks. London: Earthscan.

Guy, S., Marvin, S., \& Moss, T. (2001). Urban infrastructure in transition, networks, buildings, plans. Newcastle-on-Tyne, UK: Earthscan Publications.

Hardoy, J. E., Mitlin, D., \& Satterthwaite, D. (2013). Environmental problems in an urbanizing world: finding solutions in cities in Africa, Asia and Latin America. Routledge.

Heynen, N. (2013) Urban political ecology I: The urban century. Progress in Human Geography, 38(4), pp. 598-604

Heynen, N., Kaika, M., \& Swyngedouw, E. (2006). In the Nature of Cities - Urban Political Ecology and the Politics of Urban Metabolism. Routledge: London

Hilburn, A. M. (2015). At Home or to the Dump?: Household Garbage Management and the Trajectories of Waste in a Rural Mexican Municipio. Journal of Latin American Geography, 14(2), pp.29-52. doi:10.1353/lag.2015.0019

Hoornweg, D., Bhada-Tata, P., \& World Bank. (2012). What a waste - A Global Review of Solid Waste Management. Washington: World Bank. Retrieved from $\mathrm{http}: / /$ scholar.google.com/scholar?hl=en\&btnG=Search\&q=intitle:WHAT+A+WASTE+ $\mathrm{A}+$ Global+Review + of + Solid + Waste + Management $\# 3$

Hunt, C. (1996). Child waste pickers in India: the occupation and its health risks. Environment and Urbanization, 8(2), pp.111-118.

Huysman, M. (1994). Waste picking as a survival strategy for women in Indian cities. Environment and Urbanization, 6(2).

ILO (2013). Políticas públicas para la inclusion de los recicladores de base al sistema de gestión de residuos municipals en Chile. International Labour Organisation; Avina; 
Movimiento Nacional de Recicladores de Chile. Retrieved from http://www.ilo.org/wcmsp5/groups/public/---americas/---ro-lima/---srosantiago/documents/genericdocument/wcms_205403.pdf

Kaminer et al. (eds) (2011) Urban asymmetries: studies and projects on neoliberal urbanization. Rotterdam: 010 Publishers.

Kawai, K., Osako, M., Matsui, S., \& Dong, N. T. (2012). Identification of junk buyers' contribution to recycling of household waste in Hanoi, Vietnam, through a physical composition analysis. Waste Management \& Research : The Journal of the International Solid Wastes and Public Cleansing Association. 30(7), pp.681-8.

KDM (2014) KDM tratamiento. Retrieved 28-10-2015 in http://www.kdm.cl/tratamiento/estacion-de-transferencia.html

Keil, R. (2005). Progress report: urban political ecology. Urban Geography, 26(7) 640-651.

Kennedy, C., Cuddihy, J., \& Engel-Yan, J. (2007). The changing metabolism of cities. Journal of Industrial Ecology, 11(2), 43-59. Retrieved from http://onlinelibrary.wiley.com/doi/10.1162/jie.2007.1107/abstract

Kennedy, C., Pincetl, S., \& Bunje, P. (2011). The study of urban metabolism and its applications to urban planning and design. Environmental Pollution, 159(8-9), 1965-73. doi:10.1016/j.envpol.2010.10.022

Le Courtois, A. (2012) Municipal Solid Waste: turning a problem into resource. Private Sector \& Development, vol.15, pp.1-28

Major, D. C., A. Omojola, M. Dettinger, R. T. Hanson, R. Sanchez-Rodriguez, 2011: Climate change, water, and wastewater in cities. Climate Change and Cities: First Assessment Report of the Urban Climate Change Research Network, C. Rosenzweig, W. D. Solecki, S. A. Hammer, S. Mehrotra, Eds., Cambridge University Press, Cambridge, UK, 113143.

McFarlane, C., \& Robinson, J. (2012). Introduction: experiments in comparative urbanism. Urban Geography, 33(6), 765-773.

McFarlane, C. (2013). Metabolic inequalities in Mumbai: Beyond telescopic urbanism. City, 17(4), pp.498-503.

Medina, M. (2000). Scavenger cooperatives in Asia and Latin America. Resources, Conservation and Recycling, 31(1), pp.51-69.

Medina, M. (2005). Serving the unserved: informal refuse collection in Mexico. Waste management \& research. 23. pp. 390-397

MIDEPLAN (2015). Pobreza y distribución del ingreso en la region metropolitan de Santiago: resultados encuesta CASEN 2013. MIDEPLAN, Secretaria Regional Ministerial de Desarrollo Social. Retrieved 23-01-2016 in http://www.ministeriodesarrollosocial.gob.cl

MMA (2011). Capítulo 3 reciclaje. Ministerio del Medio Ambiente. Retrieved 09-10-2015 in http://www.mma.gob.cl/1304/articles-52016_Capitulo_3.pdf

MMA (2015). Senado despacha ley de fomento al reciclaje y responsabilidad extendida del productor. Retrieved from http://portal.mma.gob.cl/senado-despacha-ley-de-fomento-alreciclaje-y-responsabilidad-extendida-del-productor/

Moore, S. (2012). Garbage matters: Concepts in new geographies of waste. Progress in Human Geography, 36(6), pp. 780-799. 
Moreno-Sanchez, R., \& Higinio Maldonado, J. (2006). Surviving from garbage: the role of informal waste-pickers in a dynamic model of solid-waste management in developing countries. Environment and Development Economics, (03), pp.371-391.

Moss, T., Medd, W., Guy, S., Marvin, S. (2009) Organising Water: The Hidden Role of Intermediary Work. Water Alternatives, 2(1), pp.16-33

Municipalidad de Colina (2013) Responde solicitud de información. Municipalidad de Colina, Alcaldía.

Newell, J. P., \& Cousins, J. J. (2014). The boundaries of urban metabolism : Towards a political - Industrial Ecology. Progress in Human Geography. pp.1-27

Nijman, J. (2007). Introduction: comparative urbanism. Urban Geography, 28(1), 1-6.

Nzeadibe, T. C. (2009). Solid waste reforms and informal recycling in Enugu urban area, Nigeria. Habitat International, 33(1), pp.93-99. doi:10.1016/j.habitatint.2008.05.006

Orellana, A. (2009). La gobernabilidad metropolitana de Santiago: la dispar relación de poder de los municipios. EURE (Santiago), 35(104), 101-120.

Parliament (2014). Fourth report waste management in England. Environment, Food and Rural Affairs Committee, UK Parliament. Retrieved 09-06-2015 from http://www.publications.parliament.uk/pa/cm201415/cmselect/cmenvfru/241/24106.htm \#note42

Pizarro, G. and Jara, M. (2015). El mapa de Chile del millonario negocio de la basura. Ciper Centro de Investigación Periodistica. Retrieved from http://ciperchile.cl/2015/05/26/elmapa-de-chile-del-millonario-negocio-de-la-basura/\#recuadro

Ren, J., \& Luger, J. (2015). Comparative urbanism and the 'Asian City': implications for research and theory. International Journal of Urban and Regional Research, 39(1), 145156.

Robinson, J. (2015). Comparative urbanism: new geographies and cultures of theorizing the urban. International Journal of Urban and Regional Research, online early (1-15).

Rojas, C. (2013, May 17) Cerca del 27\% de las comunas en la Región Metropolitana cuenta con puntos limpios para reciclar. La Tercera. Retrieved from http://www.latercera.com

Rosado, L., Niza, S., \& Ferrão, P. (2014). A Material Flow Accounting Case Study of the Lisbon Metropolitan Area using the Urban Metabolism Analyst Model. Journal of Industrial Ecology, 18(1), 84-101. doi:10.1111/jiec.12083

Rouse, J. R. (2006). Seeking common ground for people: Livelihoods, governance and waste. Habitat International, 30, pp.741-753. doi:10.1016/j.habitatint.2005.09.001

Sabatini, F. and Wormald, G. (2004). La guerra de la basura de Santiago: desde el derecho a la vivienda al derecho a la ciudad. EURE (Santiago), 30(91), 67-86.

Santiago tiene 65 vertederos no autorizados y 700 microbasurales (2015, August 02). El Mercurio. Retrieved from http://www.economiaynegocios.cl

Sanzana Calvet, M., \& Castan Broto, V. (2016). Green enclaves, neoliberalism and the constitution of the experimental city in Santiago de Chile. In J. Evans, A. Karvonnen, R. Raven (Eds.), The Experimental City. London: Routledge.

Scheinberg, A., Spies, S., Simpson, M. H., \& Mol, A. P. J. (2011). Assessing urban recycling in low- and middle-income countries: Building on modernised mixtures. Habitat International, 35(2), pp.188-198.

Schindler, S., Kishore, B. (2015) Why Delhi cannot plan its 'new towns': The case of solid 
waste management in Noida. Geoforum. Vol. 60, pp.33-42

SEDEMA. (2015). Inventario de Residuos Sólidos de la Ciudad de México 2014.

Sembiring, E., Nitivattananon, V. (2010) Sustainable solid waste management toward an inclusive society: Integration of the informal sector. Resources, Conservation and Recycling. 54(11), pp.802-809

SINIM (2015) Base técnica fondo común municipal 2014. Sistema Nacional de Información Municipal, Subsecretaría de Desarrollo Regional y Administrativo. Retrieved 17-072016 from: http://www.sinim.gov.cl

Streicher-Porte, M., Widmer, R., Jain, A., Bader, H.-P., Scheidegger, R., \& Kytzia, S. (2005). Key drivers of the e-waste recycling system: Assessing and modelling e-waste processing in the informal sector in Delhi. Environmental Impact Assessment Review, 25(5), pp.472-491.

Sue, V. M., \& Ritter, L. A. (2012). Conducting online surveys. Sage.

Swilling, M. \& Annecke, E. (2012). Just Transitions - Explorations of sustainability in an unfair world. UCT Press: Claremont, South Africa

Swyngedouw, E. (2006). Metabolic Urbanization: The Making of Cyborg Cities, in N. Heynen, M. Kaika, E. Swyngedouw (eds) In the Nature of Cities: Urban Political Ecology and the Politics of Urban Metabolism, London: Routledge.

Terraza, H. (2009). Manejo de Residuos Sólidos: Lineamientos para un servicio integral, sustentable e inclusivo (No. IDB-TN-101). Inter-American Development Bank.

UN-Habitat (2010). Solid Waste Management in the World's cities. London: Earthscan

Urquieta, C. (2013). Consejo de Defensa del Estado se querella por polémica licitación de relleno sanitario en Maipú. El Mostrador. Retrieved from http://www.elmostrador.cl

Valencia, M. (2014, March 26). Chicureo alista proyectos para recibir a 120 mil habitantes más en la próxima década. El Mercurio, p.C11.

Valencia, M. (2015, March 03). Santiago alcanza record de cuatro millones de toneladas de basura al año en vertederos. El Mercurio, p.C6.

van Beukering, P. (1994). An economic analysis of different types of formal and informal entrepreneurs, recovering urban solid waste in Bangalore (India). Resources, Conservation and Recycling, 12, 229-252.

Vasquez, O. (2011). Gestión de los residuos sólidos municipales en la ciudad del Gran Santiago de Chile: desafíos y oportunidades. Revista internacional de contaminación ambiental, 27(4), 347-355.

Vergara, S., Damgaard, A., \& Gomez, D. (2015). The Efficiency of Informality: Quantifying Greenhouse Gas Reductions from Informal Recycling in Bogotá, Colombia. Journal of Industrial Ecology, 20(1).

Villarroel Walker, R., \& Beck, M. B. (2012). Understanding the metabolism of urban-rural ecosystems. Urban Ecosystems, 15(4), 809-848.

Wackernagel, M. (1998). The ecological footprint of Santiago de Chile. Local Environment. vol. 3 (1) 7-25.

WIEGO (nd). The urban informal workforce: Waste pickers/ recyclers. Working paper, Informal Economy Monitoring Study

Wilson, D., Araba, A., Chinwah, K., Cheeseman, C. (2009) Building recycling rates through 
the informal sector. Waste Management. 29(2), pp.629-235

Wilson, D., Rodic, L., Scheinberg, A., Velis, C., Alabaster, G. (2012). Comparative analysis of solid waste management in 20 cities. Waste Management \& Research. 30(3), pp. 237254

Wolman, A. (1965). The Metabolism of Cities. Scientific American, 213, pp.179-90. 
Title of the paper: Flows, system boundaries and the politics of urban metabolism: waste management in Mexico City and Santiago de Chile

\section{Authors Information:}

Louise Guibrunet*, Institute for Sustainable Resources, University College London

Martin Sanzana Calvet, Development Planning Unit, University College London

Vanesa Castán Broto, Development Planning Unit, University College London

* Corresponding author. Contact details:

Louise Guibrunet,

UCL Institute for Sustainable Resources,

Central House, 14 Upper Woburn Place

London WC1H ONN, United Kingdom

Email: I.guibrunet.10@ucl.ac.uk 